\title{
THE LEGAL ORIGINS OF FINANCIAL DEVELOPMENT: EVIDENCE FROM THE SHANGHAI CONCESSIONS
}

\author{
Ross Levine \\ Chen Lin \\ Chicheng Ma \\ Yuchen Xu \\ Working Paper 28794 \\ http://www.nber.org/papers/w28794 \\ NATIONAL BUREAU OF ECONOMIC RESEARCH \\ 1050 Massachusetts Avenue \\ Cambridge, MA 02138 \\ May 2021
}

We thank Ying Bai, Peter Koudijs, Luigi Pascali and Hans-Joachim Voth for helpful comments and suggestions. The views expressed herein are those of the authors and do not necessarily reflect the views of the National Bureau of Economic Research.

NBER working papers are circulated for discussion and comment purposes. They have not been peer-reviewed or been subject to the review by the NBER Board of Directors that accompanies official NBER publications.

(C) 2021 by Ross Levine, Chen Lin, Chicheng Ma, and Yuchen Xu. All rights reserved. Short sections of text, not to exceed two paragraphs, may be quoted without explicit permission provided that full credit, including $(\odot$ notice, is given to the source. 
The Legal Origins of Financial Development: Evidence from the Shanghai Concessions Ross Levine, Chen Lin, Chicheng Ma, and Yuchen Xu

NBER Working Paper No. 28794

May 2021

JEL No. G21,K4,N25,O16

\begin{abstract}
$\underline{\text { ABSTRACT }}$
We assemble new data on the British and French concessions in Shanghai between 1845 and 1936 to assess the legal origins view of financial development. During this period, two regime changes altered the degree to which the British common and French civil law traditions held jurisdiction over the respective concessions: the 1869 formation of the Mixed Courts strengthened Western legal jurisdiction, while the 1926 rendition agreement returned those courts to Chinese control. By examining the changing application of different legal traditions to adjacent neighborhoods within the same city, we address identification challenges associated with crosscountry studies. Consistent with the legal origins view, the financial development advantage in the British concession widened after the formation of the Courts and shrank after their rendition.
\end{abstract}

Ross Levine

Haas School of Business

University of California at Berkeley

545 Student Services Building, \#1900 (F685)

Berkeley, CA 94720-1900

and NBER

Ross_levine@haas.berkeley.edu

Chen Lin

Faculty of Business and Economics

The University of Hong Kong

Hong Kong

chenlin1@hku.hk
Chicheng Ma

Faculty of Business and Economics

The University of Hong Kong

Hong Kong

macc@hku.hk

Yuchen Xu

HSBC Business School

Peking University

Nanshan District

Shenzhen

China

xuyuchen@phbs.pku.edu.cn 


\section{Introduction}

The legal origins view of comparative financial development stresses that economies with a common law tradition more effectively protect outside investors than economies with a civil law tradition, especially economies with a French civil law tradition, and protecting outside investors from expropriation by corporate insiders, government officials, and others is crucial for financial development (La Porta et al. 1997, 1998). The view further asserts that legal traditions developed in Europe were spread to other countries through conquest and colonization so that researchers can exploit differences in legal origin as an exogenous determinant of legal system differences and hence financial development. An extensive body of research confirms the prediction of the legal origins view: countries with a common law tradition have more developed financial systems than those with a French civil law tradition (e.g., La Porta et al. 1997, 1998, 2002, 2006; Beck et al. 2000; Levine et al. 2000; Barth et al. 2004; Durnev and Kim 2005; Djankov et al. 2007, 2008; Morck et al. 2005; Berkowitz 2011; Brown et al. 2013; D’Acunto 2019).

However, as stressed in the review of the legal origins literature by La Porta et al. (2008), the key challenge to assessing the legal origins view is the degree to which one can interpret legal origin as an exogenous source of variation in the legal framework shaping financial development or whether legal origin proxies for something else determining financial development (e.g., Pistor 2009; Musacchio and Turner 2013). A country's legal tradition could proxy for culture (e.g., Stulz and Williamson 2003; Licht et al. 2005; D'Acunto et al. 2019), social capital (e.g., Guiso et al. 2004), politics (e.g., Glaeser and Shleifer 2002; Rajan and Zingales 2003; Pagano and Volpin 2005; Perotti and von Thadden 2006; Roe 2006), or other factors omitted from the analyses. Aware of this overarching concern, researchers have controlled for many potential confounding factors to identify the impact of differences in legal systems on the operation of financial markets (e.g., Beck et al. 2003; Djankov et al. 2003; Fisman and Love 2004; Jappelli et al. 2005; Safavian and Sharma 2007; La Porta et al. 2006, 2008; Brown et al. 2013). Yet, without randomly assigning legal systems to otherwise similar economies and then assessing the ramifications on financial development, the challenge of identifying the impact of legal origin on financial development remains.

In this paper, we exploit the unique history of Western concessions in China from 1845 through 1936 to assess the legal origins view of financial development. In Shanghai, China granted the British and French concessions over adjacent, barren, and very similar 
plots of land following the First Opium War. The British applied the common law in their concession, and the French concession used the French civil law. We evaluate the ramifications of applying the common and civil law on financial development within the same city. Besides the spatial discontinuity in legal traditions, another unique advantage of examining the Shanghai concessions is that there were pivotal changes in legal jurisdiction over the concessions during this period. Thus, we evaluate changes in the degree to which British common and French civil law shaped financial arrangements in the respective concessions. Although subject to its own identification concerns that we discuss below, examining the ramifications on financial development from applying different legal systems to different plots of land over time within the same city addresses identification challenges associated with cross-country comparisons. ${ }^{1}$

To motivate and frame our econometric strategy, we first provide a brief history of pivotal changes in legal jurisdiction over the Shanghai concessions. From the founding of the British (1845) and French (1849) concessions until 1869, legal cases were handled by the respective consulates. During this period, more Chinese individuals and businesses moved into the concessions, increasing the number of "mixed" cases involving Chinese and foreigners. In 1869, there was a major change in legal systems governing the concessions: The British and French established their own Mixed Courts to handle the full array of legal disputes, including mixed cases. The British Mixed Court used the common law, and the French Mixed Court applied the French civil law. There was another regime change in the legal systems governing the concessions in 1926. The Provisional Rendition Agreement, signed in 1926, triggered a switch from the British common law and the French civil law to the Chinese civil law in the respective concessions, returning legal jurisdiction to Chinese-run courts. British and French influence over the concessions started to wane with the Second Sino-Japanese War, so we ended our analyses in 1936. These regime changes in the legal systems governing the concessions over the 1845 to 1936 period define the key breakpoints in the difference-in-differences methodology that we describe below.

We manually collect data on bank and stock market development. Our primary measure of financial development is the number of banks (per square kilometer) in each concession and year. This bank density measure includes data on foreign banks, Chinese modern (joint-stock) banks, and Chinese traditional banks (qianzhuang). We aggregate the

\footnotetext{
${ }^{1}$ Brown et al. (2017) examine the implications of imposing federal or state courts on different Native American reservations. We study the impact on comparative financial development from imposing different legal systems on different areas of the same city.
} 
number of headquarters and branches. We have the exact location of each bank using the historical definition of streets and then mapping those addresses to GIS coordinates. We also compile annual information on the identity and location of all stock companies and their market capitalization and monthly data on stock returns. We have information on stock company density (companies per square kilometer) for the full sample period but could obtain data on stock prices only after 1894. Using these data, we assess how bank and stock market development change following changes in legal jurisdiction over the Shanghai concessions.

To assess the impact of the British common law and the French civil law on comparative financial development, we use a series of difference-in-differences strategies. In our core analyses, the first difference compares the British and French concessions. The second difference compares (1) the time period from the founding of the Shanghai concessions until Britain and France create the Mixed Courts in 1869 to (2) the time period from 1869 through the period before the rendition of those courts to Chinese control in 1926. As noted above, creating the Mixed Courts in 1869 was a regime change, as the British and French formally implemented their legal systems in their respective concessions. Thus, the legal origins view predicts that financial development in the British concession should be comparatively stronger than that in the French concession after 1869 relative to differences in financial development in the two concessions before establishing the Mixed Courts in 1869 . All of the difference-in-differences analyses include concession and year effects.

Consistent with the legal origins view of comparative financial development, financial development—bank density or stock company density-in the British concessions is materially greater than that in the French concession after 1869. Furthermore, when examining the parallel trends, there is no sign of a change in comparative financial development before 1869. Rather, there is a sharp change following the application of the different legal traditions in the concessions. Since Britain and France may differ in financial development for reasons that have nothing to do with legal origins and those differences could be reflected in the establishment of their banks in Shanghai, we also conducted the analyses focusing only on Chinese banks. We find that substantially more Chinese banks establish affiliates in the British concession than in the French concession. Furthermore, we divide the concessions into 200-by-200 meter grid cells and conduct the analyses while including grid-cell fixed effects to account for within concession variation. The results hold.

We extend these analyses to address a key challenge to drawing inferences about the impact of the British common law and the French civil law on comparative financial 
development from these analyses: omitted variables. First, non-legal system differences between Britain and France could have shaped comparative economic development in the concessions with concomitant ramifications on comparative financial development. Thus, we control both for population density in the respective concessions and Gross Domestic Product (GDP) in each respective homeland (i.e., the GDP of Britain for the British concession and the GDP of France for the French concession). All of the results hold. Second, we were concerned that differences in British and French governance systems within the concessions could account for the differences in financial development. Although we include concession fixed effects, we extend these analyses by explicitly controlling for when the British and French formally established different governance systems in their respective concessions. In particular, the British established their Municipal Council in 1854, and the French creating their own Municipal Council in 1862. However, controlling for these breaks in governance does not alter the findings that there was a sharp change in financial development in the two concessions following the establishment of the British and French Mixed Courts in 1869. Third, we were also concerned that the formation of the concessions in the 1840 s could have set in motion different financial system dynamics that are not fully captured by the concession and year fixed effects or the additional controls just discussed. Besides these controls, we also include the interaction between a British concession dummy variable and both linear and quadratic trends. Consistent with the view that the British common law fostered comparatively strong financial development in the British concession relative to that in the French concession, the results hold when conditioning on all of these potentially confounding influences.

The history of legal jurisdiction over the Shanghai concessions offers an additional and unique way to identify the impact of legal origins on comparative financial development: the rendition of the Mixed Courts in 1926. Without changing the administration of the concessions, the rendition returned legal jurisdiction of the concessions to Chinese-run courts. The legal origins view predicts that since the British common law provides a comparative advantage over the French civil law in supporting financial development, the rendition of the Mixed Courts will negatively affect financial development more in the British concession. To test this prediction, we again employ a difference-indifferences approach. In these rendition analyses, the first difference again compares the British and French concessions. The second difference now compares the years before the rendition of the Mixed Courts to Chinese control in 1926 to the years after the rendition. 
The results from the rendition analyses are consistent with the legal origins view of comparative financial development. The British concession experienced a much sharper decline in both bank density and stock company density following 1926. Evidence from changes in stock returns further supports the legal origins view. We examine a 24-month window around the August 1926 Provisional Rendition Agreement. We discover that stock returns in the concessions fall materially following the rendition of the Mixed Courts, and the fall is disproportionately large among firms in the British concession.

Our joint findings that (a) the financial development advantage of the British over the French concession emerges with the application of the British common law and French civil law in the respective concession in 1869 and (b) the financial development gap shrinks with the rendition of the British common law and French civil law to Chinese-run courts after 1926 suggest that the different legal systems help shape comparative financial development. Evidence on stock returns further supports this view.

As a final extension, we examine concessions in three cities outside of Shanghai: Guangzhou, Hankou, and Tianjin. In particular, we study 16 concessions granted to countries with either a common law (Britain and the United States) or civil law tradition (AustroHungarian Empire, Belgium, France, German, Italy, Japan, and Russia). We analyze these three cities because each contains within its borders at least one common and one civil law concession. Thus, we compare financial development across concessions with different legal systems in the same city. There are limitations to examining these 16 concessions, however. These concessions did not experience the sharp intertemporal breakpoints in legal jurisdiction that characterize the Shanghai concessions. This limitation reduces the ability to distinguish the effects of legal tradition on comparative financial development from other features of the concessions that might shape financial development. Nevertheless, we provide these analyses to augment the examination of the Shanghai concessions. Consistent with the Shanghai results, we discover that financial development is materially greater in the common law concessions than in their civil law counterparts. Furthermore, when limiting the analyses to British and French concessions, we find that the British common law concessions are comparatively more financially developed than the French civil law.

The remainder of the paper is organized as follows. Section 2 provides a more detailed history of the Shanghai concessions. Section 3 describes the data. Section 4 presents the results analyzing changes in comparative financial development after Britain and France created the Mixed Courts. Section 5 details the analyses and findings on changes in comparative financial development associated with the rendition of the courts to Chinese 
rule. In Section 6, we investigate the relationship between different legal systems and comparative financial development in cities outside of Shanghai. Section 7 concludes.

\section{Shanghai Concessions}

In 1845, the British concession in Shanghai was formally established after Britain defeated China in the First Opium War (1839-1842) and forced the Qing Dynasty to cede 830 acres of land in Shanghai to Britain. In later years, China agreed to Britain's request to expand the concession as the number of foreign and Chinese settlers increased. The United States also received a concession in Shanghai that bordered the British concession. The British and American concessions merged in 1863, which was later named the Shanghai International Settlement. It reached a maximum size of 33,503 acres in $1899 .{ }^{2}$ Britain dominated the administration of the International Settlement. For example, British citizens accounted for about $90 \%$ of the executive members of the concession's Municipal Council (Wang 1998). For this reason, we follow the literature and use the term "British concession" in referring to the International Settlement. In 1849, the French also established a concession in Shanghai that bordered the British concession. The French concession also experienced several expansion waves, from the original 164 acres to over 15,000 acres in 1914. Figure I illustrates the geographic expansion of the Shanghai concessions.

After 1936, British and French influence over the concessions waned appreciably with the Second Sino-Japanese War (1937-1945). As a result, we end our analyses of the Shanghai concessions in 1936. Both the British and French concessions were formally returned to the Chinese government in 1943.

\subsection{The British and French legal systems in the concessions}

Britain and France transplanted their common law and civil law legal systems into their respective Shanghai concessions. During the initial decades, the British and French consulates handled disputes involving their own citizens. As more Chinese moved into the concessions and economic activity boomed, the British and French consulates struggled to address the burgeoning array of "mixed" cases that involved financial and commercial disputes between Chinese and foreign individuals, firms, and banks. In 1863, officials began negotiating an arrangement to replace these consular courts with legal institutions that could better serve the community's needs (Hudson 1927).

\footnotetext{
${ }^{2}$ More than ten countries had consulates within the International Settlement, but they did not play a material role in administering the Settlement (Wang 1998).
} 
In 1869, a new charter was finalized, and both the British and French concessions established their own Mixed Courts (Huishen Gongxie) to handle cases involving Chinese and foreign plaintiffs and defendants. ${ }^{3}$ During the initial decades of the Mixed Courts, Chinese and foreign judges jointly heard cases involving Chinese citizens and foreign residents (see an illustration in Appendix Figure A1), but foreign judges dominated the courts. As noted by the U.S. State Department (1880, p. 158), Chinese officials mainly assisted in executing decisions. Research by Hudson (1927), Yang (2006), and Cai (2013) notes that the Chinese officials participating in the Mixed Courts (a) tended to have a very low rank within the Chinese hierarchy, (b) were chosen by foreign officials to serve in the Mixed Courts, and (c) had little to no influence over decisions. By 1911, the Mixed Courts had jurisdiction over civil cases, including cases involving only Chinese citizens within the concessions, as well as the appointment, supervision, and payment of Chinese judges, control over prisons, the execution of arrests, etc. (Hudson 1927; Shanghai Shehui Kexueyuan 1981).

Around 1926, there was another "regime change" in the legal system governing the concessions. Due to rising nationalism after the First World War, China began negotiating a plan of rendition, whereby the Mixed Courts would surrender legal jurisdiction to the Chinese authorities (Hudson 1927). These negotiations started in 1916 but failed to reach an agreement. In 1925, there were violent demonstrations in the concessions over foreign "imperialism" that reenergized negotiations about rendition. An agreement, the "Provisional Rendition Agreement," was signed on August 31, 1926, and the formal rendition of the British Mixed Courts to Chinese-run courts occurred on January 1, 1927. This was a major change as it involved a switch from British common law to Chinese civil law. The French Mixed Court was also materially altered in 1927, as Chinese cases were assigned to Chinese judges and lawyers. Then, in 1931, Chinese courts assumed legal jurisdiction over the French concession.

\subsubsection{Common law in the British concession}

The historical record of lawsuits demonstrates that the British concession followed a British common law tradition. The courts decided cases based on statutory law, precedent,

\footnotetext{
${ }^{3}$ There were clear, formal jurisdictional boundaries between the Mixed Court of the International Settlement (British Mixed Court) and the Mixed Court of the French Settlement that specified which of the Mixed Courts would adjudicate cases. The Statutes of the Mixed Courts in Shanghai, which was issued on April 20, 1869, determined these jurisdictional boundaries. Jernigan (1905, pp. 203-4) details the rules governing jurisdiction.
} 
and the application of those laws and precedents to emerging cases within the concession. ${ }^{4}$ In the concession, the British common laws applied to both foreign residents and local Chinese. With the accumulation of court cases in the concession, the Court gradually invoked local cases as precedents in deciding new cases (e.g., Levine 2005). For example, in a 1911 case, an American publishing house, Messrs, Ginn \& Co., sued the Commercial Press of China for copyright infringement. The lawyer cited two verdicts from earlier cases in 1896 and 1907 within the British concession in which Chinese businesspeople were convicted of pirating foreign books. The American publishing house won the case, and Commercial Press had to recompense Messrs, Ginn \& Co. This case is discussed in a series of newspaper reports in the North China Herald, April 8, April 10, and October 7, 1911, and Hou (2017).

Another noteworthy feature of the common law is its ability to adapt and consider local circumstances and customs in addressing specific cases. Evidence of this feature exists in the British concession, as legal practitioners regularly referred to Chinese customs when addressing disputes. Thus, without violating common law principles, the law could sometimes evolve efficiently in the British concession to resolve disputes while respecting local customs. For example, in 1876, Sassoon \& Co., Ld., E.D. sued Wang, the owner of a Chinese company, in the mixed court for overdue payment of a promissory note. Wang argued that the promissory note with 500 tael principal was transferred to the Chinese merchant Guo to purchase opium. However, the opium business of Guo went bankrupt, which led to the suspension of the repayment of the note. The verdict was that since there is a stamp of the Chinese company on the promissory note, Wang must repay the note to Sassoon $\&$ Co. The judgment was based on the Chinese convention that the validity of notes depends on an official Chinese seal. If there is a default on the payment, the issuer with a seal on the promissory note is financially responsible. ${ }^{5}$

\subsubsection{Civil law in the French concession}

Consistent with the French civil law tradition, the French Mixed Court decided cases based on the statutes passed in France, not based on precedent or local custom. The Court's archives show that judges resolved commercial cases based on strict applications of French

\footnotetext{
${ }^{4}$ We confirmed the operation of the British common law in the Shanghai concession by reviewing commercial and financial lawsuits regarding property rights, financial instrument transactions, bankruptcy, creditors' residual rights after the liquidation of a company, and shareholders' rights and shares in joint ventures. It is worth noting that well-developed law libraries emerged in the Municipal Council of the British concession, which facilitated the law practitioners of the day and our research.

${ }^{5}$ Cai (2013) cites this case, which is discussed in the article "Case on opium business promissory note (Zhipiao Fayin)" from the Chinese daily newspaper, Shun Pao, on January 22, 1876.
} 
commercial codes. ${ }^{6}$ For example, in 1910, a French merchant sued a Chinese broker who traded gold futures for him, charging that the speculative behavior of the Chinese broker resulted in the French merchant losing more than 10,000 silver taels. Citing Section 1965 of the French Civil Code on the recovery of debts, the French court rejected the French merchant's argument, reasoning that the contract did not specify precise limits on trading by the Chinese broker. So, there was no basis for classifying the broker's trade as illegal (Hou (2017) cites this case "Séance du 27 November 1907 S. Somekh contre Hi Kai Song" [no. 635PO/C/371] from the Nantes branch of the French Ministry of Foreign Affairs Archives.)

Also consistent with the French civil law tradition, judges in the French concession exerted power over investigating cases, calling and questioning witnesses, etc. Accordingly, lawyers in the French concession - as in France - mainly dealt with drafting and submitting documents to the court and replying to judges' queries (Hou 2017).

\subsection{Financial development}

The concessions were established on relatively undeveloped land, with few prior inhabitants and no pre-existing financial institutions or markets. For example, Montalto de Jesus's (1919, pp. 27-29) history of Shanghai describes the land ceded for the British concession as uncultivated, with several creeks and a few small hamlets. Likewise, French settlers described the initial condition of their concession as "primitive, covered with houses in poor condition, graves, and rubbish dumps." (Fauvel, 1899. p.17)

By the late $19^{\text {th }}$ century, however, Shanghai had become the largest financial hub in Asia, and the British concession was the financial center of Shanghai. For example, two years after the foundation of the British concession, the English Oriental Bank opened its first branch in China within the British concession. Foreign banks steadily entered the British concession, reaching 30 by 1925 . In contrast, the total number of foreign banks in the French concession reached only four in the same period. These foreign banks dominated the foreign exchange market and the financing of foreign trade.

Over time foreign banks collaborated with Chinese traditional banks called qianzhuang ("money house") to provide a wider range of financial services to local businesses. The qianzhuang were generally small sole proprietorships or partnerships in which the founders were from wealthy merchant families. The qianzhuang blossomed in Shanghai after the mid- $19^{\text {th }}$ century. Their activities included providing local currency

\footnotetext{
${ }^{6}$ The cases are reserved in the Archives du Ministère de la France des Affaires Etrangère (Archives of the French Ministry of Foreign Affairs).
} 
exchanges for the varieties of metallic currencies circulating in China, note-issuing, and giving credit to firms and households. While foreign banks had abundant capital, qianzhuang had local expertise. The two financial intermediaries formed fruitful business relations in the Shanghai concessions. Indeed, many qianzhuang moved their headquarters into the concessions, and the qianzhuang even relocated their Association (Shanghai qianye gonghui) from the Shanghai old city to the British concession in 1917.

In 1897, the Imperial Bank of China - the first "modern" Chinese bank-opened in the Shanghai British concession. Unlike the qianzhuang, the Imperial Bank of China was a limited liability, joint-stock company, with regular shareholder meetings, a separate board of directors, and financial and accounting disclosure statements based on international standards. Many such modern Chinese banks soon emerged. By 1925, the number of Chinese banks in the British concession reached 194, more than five times the number of foreign banks (30). However, the number of Chinese banks in the French concession grew much less rapidly, reaching 29 banks in 1925.

Besides modern banks, nonfinancial Chinese stock companies with limited liability and traded shares also flourished in the Shanghai concessions (Wang 1965). Investors could purchase stocks directly from the company or through qualified brokers (Liu 2004). An active secondary market emerged in the 1860s. The most influential newspaper in Shanghai, The North-China Herald, published daily stock prices in the section "Shares and Stocks" (see Appendix Figure A2). During the early years, the trading of stocks was conducted mainly through foreign banks and foreign stock trading companies. The Shanghai Share Broker's Association was founded in 1891, giving rise to The Shanghai Stock Exchange in 1903. As shown in Figure II, most of the publicly traded stock companies were located in the British concession. For example, by 1925, there were 74 publicly-traded companies in the British concession and four in the French concession.

\section{Data}

\subsection{Unit of geographic analysis}

We compare the development of finance in the British and French concessions from the establishment of the British concession in 1845 until the eve of the Second Sino-Japanese War in 1936, which reduced Western dominance over the concessions. We define the geographic boundaries of the concessions as those lands that were part of the concessions before 1861, which we call the "old concessions." The results, however, are robust to using 
the post-1861 geographic boundaries of the concessions. Figure I provides a map of the British and French concessions in Shanghai. As noted above, the British and French established their concessions on similar and fairly barren lands. Nevertheless, we account for potential variation in land quality, infrastructure, and other location-specific effects by dividing the concessions into $100200 \mathrm{~m} \times 200 \mathrm{~m}$ grid cells and including grid cell fixed effects in the analyses below. ${ }^{7}$ Appendix Table A1 provides descriptive statistics of the main variables that we now describe.

\subsection{Banks}

Our primary measure of financial development is the number of banks in a concession in a year, as banks were the primary financial intermediaries in the late $19^{\text {th }}$ and early $20^{\text {th }}$ centuries. Banks in Shanghai included foreign banks, Chinese modern banks, and Chinese traditional banks (i.e., the qianzhuang described above). We aggregate the number of headquarters and branches of these banks to measure financial development. ${ }^{8}$ When examining grid cells, we compute the number of headquarters and branches within each grid cell.

To obtain these data, we manually collected information on each bank's address (using the historical definition of streets and addresses in Shanghai) and years of operation from the Shanghai Financial Gazetteer and other archives and newspapers (Appendix B lists the data sources). We then map the addresses to the coordinates in the geographic information system (GIS) and identify the banks within concessions and grid cells. There were 67 foreign banks, 335 Chinese modern banks, and 264 qianzhuang in the two Shanghai concessions from 1846 through $1936 .{ }^{9}$

\subsection{Stock market}

We measure stock market development in Shanghai using either the number of stock companies or the total market capitalization of listed firms within a concession (or grid cell). We obtain stock market information from the North-China Herald, the main source of stock market information during the operation of the concessions. The Herald was founded in 1850 . It began to publish stock prices in 1864 and the number of shares in 1894.

\footnotetext{
${ }^{7}$ Specifically, we exclude grid cells that are less than $0.001 \mathrm{~km}^{2}$, which leaves 100 grid cells.

${ }^{8}$ Only foreign and Chinese modern banks had branches. Chinese qianzhuang had only one office (headquarters).

${ }^{9}$ These numbers omit the 43 Chinese modern bank branches and 86 qianzhuang for which we could not identify precise location data.
} 
For our analyses of stock market development, we were able to obtain the exact address of 205 companies located in Shanghai. ${ }^{10}$ We manually identified each stock company's location (coordinates) based on The Desk Hong List, a bi-annual survey of all Shanghai firms edited by the North-China Herald between 1872 and 1941. The survey provides detailed information on each company's name, location, business scope, and other characteristics. Then we mapped the companies to the grid cells of the two concessions. Consistent with the distribution of banks, Figure II shows that the British concession also had a much higher density of stock companies than the French concession.

Figure III depicts the distribution of banks and stock companies across the grid cells in the two concessions, using the geographic boundaries of the "old concessions." The figure provides the distributions of banks and stock companies in both 1868, which is just before the creation of the Mixed Courts more firmly established the British common law and French civil law in the respective concessions, and in 1925, which is just before the rendition of the Mixed Courts to the Chinese civil law courts. As shown, there is much more rapid financial development in the British concession relative to that in the French concession.

\section{Financial Divergence between the British and French Concessions}

\subsection{Methodological overview}

The key challenge to assessing the impact of the British common law and the French civil law on comparative financial development in their respective Shanghai concessions is isolating the influences of legal system differences from other potential factors. As noted above, the British and French concessions were on neighboring lands of similar quality that had similar pre-concession levels of economic development. Britain and France, however, were different in other potentially important respects besides their legal systems. As a result, commerce and finance might have evolved differently in the British and French concessions for reasons having little to do with legal systems.

To identify the independent role of legal system differences in shaping financial development in the two Shanghai concessions, we use a series of difference-in-differences strategies to control for many potential confounding factors. In this section, we (1) begin with a simple framework in which we explore differences in financial development between the two concessions following the formation of the concessions in 1845 to assess the "concession effect;" (2) then also assess the "legal effect" by examining differences in financial

\footnotetext{
${ }^{10}$ We omit from our analyses 75 firms for which we could find no information about their location.
} 
development in the two concessions following the formation of the Mixed Courts in 1869; and (3) including many controls to reduce the possibility that other factors, besides the legal effect associated with the establishment of the Mixed Courts, account the findings. In the next section, we turn to an additional break in the legal systems governing contracting in the concessions: the rendition of the Mixed Courts to the Chinese authorities.

\subsection{Preliminary benchmark: The concession effect}

As a preliminary benchmark, we begin with the following difference-in-differences equation to assess the impact of the two concessions on comparative financial development,

$$
Y_{i t}=\beta_{1} \times \text { British }_{i} \times \text { Post } 1845+\gamma_{i}+\lambda_{t}+\varepsilon i t,
$$

where $Y_{i t}$ denotes the number of banks $\left(\right.$ per $\mathrm{km}^{2}$ ) in a concession (or grid cell) $i$, in year $t$. British $_{i}$ is a dummy variable that equals one for the British concession (including all grid cells within the British concession when conducting the analyses at the grid-cell level) and zero for the French concession. Post1845 is a dummy variable that equals one after 1845 and zero before then. The interaction term, British $\times$ Post1845, captures the concession effect, i.e., whether more banks started operating in the British concession relative to the French concession after 1845. Since there were no banks in the concessions before 1845, the estimated coefficient on British ${ }_{i} \times$ Post 1845 provides an estimate of the average annual difference in bank density between the British and French concessions following the creation of the concessions. $\gamma_{i}$ is a concession (or grid-cell) fixed effect, which captures all time-invariant characteristics of the geographic location. $\lambda_{t}$ is a year fixed effect and captures the common annual shock shaping financial development in both the British and French concessions. ${ }^{11}$ We conduct the estimation using data from 1840 through 1926, where the $1840-1845$ period is the pre-concession period.

The estimates in Table I indicate that bank density grew much faster in the British

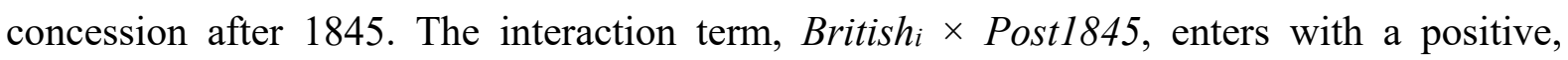
statistically significant, and economically large coefficient. The estimated coefficient in column (1) indicates that the British concession had 18 more banks per $\mathrm{km}^{2}$ than the French

\footnotetext{
${ }^{11}$ Since there are only two concessions and we include concession fixed effects, we do not adjust standard errors for clustering at the concession level when running concession level regressions, consistent with Abadie et al. (2017). However, the concession-level results are robust to clustering. When running gridcell level regressions, we adjust the standard errors for clustering at the grid-cell level. The grid-cell level results are robust to not clustering.
} 
concession during the average year from 1846 through 1925. As a reference point, there were four banks per $\mathrm{km}^{2}$ in the French concession on average during the same period.

To shed additional empirical light on the comparative advantages offered by the British concession for bank development, we extend these results in two ways. First, as shown in column (2), many more Chinese banks chose to establish affiliates in the British concession. We estimate that the average annual gap in the number of Chinese banks per $\mathrm{km}^{2}$ is about 14 greater in the British concession than in the French concession. This estimate for Chinese banks is close to the estimate in column (1) for all banks, suggesting that the concession effect on banking is primarily composed of the growth of Chinese banks. Second, we were concerned that the British concession might have some especially appealing areas for financial development, perhaps due to land quality, location, or infrastructure. It might be these within concession factors that account for comparative financial development in the British concession and not legal system differences. Thus, we conduct the analyses at the grid-cell level. As shown in columns (3) and (4) of Table I, the results hold. These results are consistent with the view that the establishment of the Shanghai concessions led to much faster financial development in the British concession than in the French concession.

\subsection{Results: The Mixed Courts and bank density}

We next extend the econometric strategy to examine the relationship between the formation of the Mixed Courts and comparative financial development while controlling for the pure concession effect. In this extended difference-in-differences strategy, the first difference involves comparing the British to the French concession. The second difference involves comparing (1) the time period from the founding of the Shanghai concession in 1846 through the creation of the Mixed Courts in 1869 to (2) the time period from 1870 to the rendition of those courts in 1926. The establishment of the Mixed Courts represents a distinct break in the concessions. The creation of these courts deepened and broadened the jurisdiction of the British and French legal systems in their respective concessions. Thus, the "legal origins" view of LLSV (1998) suggests that financial development in the British concession should be comparatively stronger than that in the French concession after 1869 relative to differences in financial development in the two concessions before the establishment of the Mixed Courts. We empirically evaluate this view.

More specifically, we use the following regression specification: 


$$
Y_{i t}=\beta_{1} \times \text { British }_{i} \times \text { Post1845 }+\beta_{2} \times \text { British }_{i} \times \text { Post } 1869+\gamma_{i}+\lambda_{t}+\varepsilon_{i t}
$$

where $Y_{i t}$, British, and Post 1845 are defined above. The second interaction term, British ${ }_{i} \times$ Post 1869, captures the legal effect, i.e., whether more banks were opened in the British concession relative to the French concession after their respective legal systems became more prominent in the concessions following the creation of the Mixed Courts in 1869. By controlling for the concession effect, British $h_{i}$ Post1845, the estimated coefficient on the legal effect, British $\times$ Post1869, provides information on whether bank density rose comparatively faster in the British concession after the establishment of the Mixed Courts in 1869 beyond any differences in the evolution of bank density triggered by the establishment of the two concessions in 1845. Thus, $\beta_{2}>0$ would suggest that bank density rose in the British concession relative to the French concession after establishing the different legal systems in the concessions.

As shown in Table II, the results indicate that bank density in the British concession was markedly greater than that in the French concession after establishing the Mixed Courts in 1869. Based on the coefficient estimates from column (1), the British concession had about 2.5 more banks per $\mathrm{km}^{2}$ on average than the French concession before establishing the Mixed Courts in 1869, and this gap increased by about 22 banks per km² after 1869 . In column (2), we re-do these analyses for the subsample of Chinese banks. The estimates indicate a comparatively sharp increase in the density of Chinese banks in the British concession, with the gap increasing by about 20 banks per $\mathrm{km}^{2}$ after the establishment of the Mixed Courts. By comparing columns (1) and (2), the estimates suggest that the legal effect is primarily composed of a large increase in Chinese banks in the British concession following the stronger application of the British common and French civil laws triggered by the establishment of the Mixed Courts. Furthermore, as shown in columns (3) and (4), these results hold for the full sample of banks and the subsample of Chinese banks when conducting the analyses at the grid-cell level. ${ }^{12}$

\footnotetext{
${ }^{12}$ Moreover, to reduce the possible heterogeneous effects of legal system differences in the concessions across different political regimes in China, we restrict the sample period to the Qing dynasty only, i.e., 1840 to 1910 . The results remain robust (see Supplementary Appendix Table A2). We also replicated Table II using five-year intervals of the data to mitigate annual fluctuations in the number of banks. Again, the results hold (see Supplementary Appendix Table A2).
} 


\subsection{Mixed Courts and bank development: Extensions}

In this section, we conduct several additional analyses to identify better the relationship between changes in the operation of the legal systems in the concessions and comparative financial development. In particular, although the findings in Table II that bank density in the British concession rose appreciably relative to that in the French concession after 1869 while controlling for the pure concession effect, British $h_{i} \times$ Post1845, concession fixed effects, and year fixed effects is consistent with the view that stronger financial development in the British concession is related to legal system differences per se, the analyses do not eliminate all potential confounding effects. Thus, we now engage in a series of analyses to reduce such concerns and better identify the impact of legal system differences on comparative financial development. Since we control for time-varying features of each concession in many of these analyses and these data on each concession do not exist before the formation of the concessions, we start these investigations in 1846.

First, despite starting from similar economic conditions, many factors besides legal system differences may have shaped economic development in the British and the French concessions. It might be these other factors and their effects on economic development that drove the divergence in bank development. To address this concern, we control for the evolution of economic development in the concessions. In particular, we control for Population density (lag), as there are no data on production in the concessions. We use lagged population density at the concession-year level to assess the robustness of our results while recognizing that these population data are subject to several challenges (Zou, 1980; Henriot et al, 2018). ${ }^{13}$ As shown in column (1) of Table III, all of the results hold when controlling for Population density (lag), suggesting that the legal effect is not driven by economic development in the two concessions.

Second, stronger financial development in Britain's Shanghai concession could reflect comparative economic development in Britain during the late $19^{\text {th }}$ and early $20^{\text {th }}$ centuries (La Porta et al. 2008) rather than the comparative advantage of the British

\footnotetext{
${ }^{13}$ From 1865 , both concessions conducted population census surveys every five or ten years. Annual population data start in 1900 in the British concession and the late 1920s in the French concession. Assuming a linear growth rate of population, we interpolated the annual population for the missing years and coded the population as zero in 1845 . Another challenge to working with population data is that we do not have separate time series data on the geographic areas defined as the old concessions (our sample areas). Instead, we use the whole population of the British and French concessions, as the districts of the old concessions were the most populous. We make this assertion based on the data illustrated in Supplementary Appendix Figure A3 for the population distribution at the district level within the concessions in 1935, which is the only year with district-level population data across concessions.
} 
common law over the French civil law. To test this, we control for the GDP of Britain when assessing financial development in the British concession and the GDP of France when assessing bank density in the French concession. Maddison (2010) provides data on GDP. In particular, we create a variable Homeland's GDP that equals (a) the GDP of Britain in year $t$ when examining bank density in the British concession in year $t$ and (b) the GDP of France in year $t$ when examining bank density in the French concession in year $t$. We find that Homeland's GDP is positively associated with financial development. More critically, we find that the legal effect is robust to controlling for Homeland's GDP. As shown in column (2) of Table III, British*Post1869 continues to enter positively, significantly, albeit with a smaller estimated coefficient than when we do not control time-varying concession traits. The estimated level of bank density is comparatively greater in the British after controlling for economic development in Britain and France.

Third, Britain and France also established different governance institutions in Shanghai, and it could be these governance systems and not comparative legal institutions that shaped financial development. Although we control for concession fixed effects and show that the legal effect holds when controlling for British*Post1845, we extend these analyses by controlling for the dates when the British and French formally established different governance systems in their respective concessions. In particular, historians highlight two substantial changes in the governance of the concessions: the British establishing their Municipal Council in 1854 and the French creating their own Municipal Council in 1862. Based on these changes, we test whether differences in governance systems account for the divergence in bank density in the concessions. To do this, we create the variable Municipal Councils, which equals one after 1854 for British concession observations, equals one after 1862 for French concession observations, and equals zero otherwise. As reported in column (3) of Table III, Municipal Councils does not enter significantly, but the legal effect, British*Post1869, continues to enter positively, statistically significantly, and with almost the identical estimated coefficient. Moreover, we simultaneously control for Population density, Homeland's GDP, and Municipal Council. As shown in column (4), the findings on British*Post1869 hold when controlling for these other features.

Fourth, we were concerned that the formation of the concessions in 1845 might have triggered different dynamics in the evolution of bank density in the two concessions. We control for linear and quadratic trends that are interacted with the 
British dummy variable to address this concern. We conduct this examination while continuing to condition on Population density, Homeland's GDP, Municipal Council, and concession and year fixed effects. As shown in column (5) of Table III, British*Post1869 continues to enter positively, significantly, and with almost the same estimated coefficient.

We replicate all of the above tests on a subsample of only Chinese banks. As shown in columns (6) - (10) of Table III, the results hold. We find that the estimated coefficient on the legal effect changes little across the different specifications, again suggesting that the legal effect on banking is primarily composed of the growth of Chinese banks.

Fifth, to provide additional evidence on whether there is a break in the comparative evolution of bank density in the British and French concessions after forming the Mixed Courts in 1869, we estimate a dynamic version of equation (1). Specifically, we run the following regression at the grid cell level with 1869 as the reference point:

$$
Y_{i t}=\sum_{t=1864}^{1879} \beta_{t} \times \text { British }_{i} \times \theta_{t}+\gamma_{i}+\lambda_{t}+\varepsilon_{i t}
$$

where $\theta_{t}$ equals one in year $t$ and zero otherwise, and the other variables are defined above. To limit the effects of heterogeneity over longer periods and focus on a narrower time period around the 1869 establishment of the Mixed Courts, we conduct this examination over the window from 1864 through 1879, i.e., five years before the Mixed Courts were established and 10 years thereafter. Note, however, that if we conduct the analyses over a longer period, the same results emerge. We then plot the estimated values and confidence intervals around $\beta_{t}$ in Figure IV. If the establishment of the Mixed Courts is associated with a positive change in the comparative evolution of financial development in the British concession, we should see an increase in $\beta_{t}$ after 1869.

As shown in Figure IV, the gap in British-French bank density is close to zero and does not exhibit a significant trend before the formation of the Mixed Courts, and then there is a distinct break. After 1869, bank density rises faster in the British concession than in the French concession. These findings suggest that the financial gap between the British and French concessions began in 1869 and then widened. 


\subsection{Stock market}

Following the same empirical strategy, we examine comparative stock market development in the British and French concessions. We continue to assess whether there was a break in financial development following the establishment of the Mixed Courts in 1869, which involved the full application of the British common and French civil legal systems in their respective concessions. To measure stock market development, we use the density of stock companies at the concession and grid-cell levels. The sample period begins in 1866, as there were no stock companies in Shanghai before then. We report the results in Table IV.

Consistent with the findings on bank density, we find that there are, on average, 10 more stock companies per $\mathrm{km}^{2}$ in the British concession than in the French concession following the establishment of the Mixed Courts. These results are robust to including concession and year fixed effects. Furthermore, we confirm these findings when examining the number of stock companies within each grid cell.

\section{Rendition of the Courts}

Another legal system break occurs around 1926 with the rendition of the Mixed Courts. Following violent protests in 1925 against Western influence, including against British and French control over the courts in the concessions, there was an intensification of negotiations about the rendition of the Mixed Courts. The Chinese and the United Kingdom signed agreement in August of 1926, and the formal rendition of the British Mixed Court to the Chinese authorities occurred on January 1, 1927. Legal jurisdiction in the French concession was also reformed. Chinese courts took over cases involving Chinese citizens in 1927, and by 1931, the Chinese courts assumed full legal jurisdiction over the French concession.

This section tests whether financial development deteriorated comparatively rapidly in the British concession following the rendition. If the British common law provides a comparative advantage over other legal systems in supporting financial development, then eliminating this advantage should have an especially large adverse effect on finance in the British concession. We examine a ten-year period around the rendition year so that our sample covers from 1917 through 1936.

To illustrate the relationship between the rendition of the Mixed Courts and comparative financial development, consider Figure V. Here, we graph the difference 
between bank density in the British and French concessions from 1917 through 1936. As shown, there is a discrete change in the bank density gap associated with the rendition. This figure helps motivate our statistical assessment.

We again employ a difference-in-differences strategy. The first difference involves compares the two concessions. The second difference involves comparing (1) the time period from 1917 to the rendition of those courts in 1926 to (2) the time period from the 1926 rendition until 1936 when the Second Sino-Japanese War effectively ended British and French influence in the Shanghai concessions. The legal origin view predicts a stronger decline in financial development in the British concession relative to that in the French following the rendition of the Mixed Courts because removing the British common law will have had a larger adverse impact on financial development than removing the French civil law. As explained above, we use 1926 as the rendition date for the difference-in-differences estimation even though official rendition occurred on January 1, 1927, because the agreement was negotiated during 1926 and finalized in August of 1926. In robustness tests, using 1927 instead of 1926 as the breakpoint date in the regressions yields almost identical results.

As reported in Table $\mathrm{V}$, the British concession experienced a much sharper decline in financial development than the French concession after 1926. Column (1) indicates that bank density fell significantly. Comparing the average year in the pre- and post-rendition periods, the estimated coefficient on British*Post1926 indicates that bank density (banks per $\mathrm{km}^{2}$ ) fell by 8 more in the British concession than in the French concession. This is large, as the bank density in the British concession at the start of the sample period (1917) was 46 per $\mathrm{km}^{2}$, while it was 5.5 per $\mathrm{km}^{2}$ in the French concession. As shown in columns (2) and (3), we find similar results when examining the density of stock companies in the concessions or the market capitalization of those firms. For example, the estimates indicate that the British concession lost about 11.6 more companies per $\mathrm{km}^{2}$ than the French concession after 1926. To gauge the size of this estimated drop, note that the density of stock companies in the British concession at the start of the estimation period (1917) was 34.3 per $\mathrm{km}^{2}$. As a robustness test, we re-do these analyses while using a narrower window (five-year window) around the rendition. As shown in columns (4) - (6), all results hold when using only a sample period of five years before and after 1926 .

Another way to shed empirical light on the impact of the rendition of the Mixed Courts is to examine the comparative change in the stock returns of firms in the British and French concessions following 1926, which we offer in Table VI. To do this, we 
examine the 24 months before and after August in 1926 (time of court rendition). The dependent variable is the monthly stock return of each company, defined as the log difference of month-end stock prices, i.e., $\log \left(\right.$ price $\left._{t}\right)-\log \left(\right.$ price $\left._{t-1}\right)$. The stock return regressions control for time-varying firm characteristics - the logarithm of the firm's market capitalization and the number of months since the firm went public (i.e., duration) - and several specifications also condition on company fixed-effects to control for time-invariant traits. To provide a benchmark, we examine the overall 'event effect' on stock returns without distinguishing between the British and French concessions (columns 1 and 2). Column (1) excludes firm fixed effects, while column (2) includes them. As shown, there is a significant drop in stock returns following the rendition of the Mixed Courts, with returns falling by about 5.5\% when including the full set of conditioning variables. We then examine the differential stock return response by including the interaction term, British*Post-Rendition, and report the results in columns (3) and (4). In column (3), we exclude the firm fixed effects and include British as a separate linear term. In column (4), we include firm fixed effects, so British drops from the estimation. The results indicate that stock returns fall by more in the British concession than in the French concession following the rendition of the Mixed Courts. Indeed, the average British firm falls more almost 6\%. The Table VI results provide further evidence that is consistent with the view that shifting from the British common law to the Chinese civil law had a more adverse effect on firms than the concomitant legal systems changes occurring in the French concession.

\section{Beyond Shanghai}

In the section, we expand our analyses to concessions outside of Shanghai. Although Shanghai was the financial center of China in the late $19^{\text {th }}$ and early 20 centuries and there are much better data on the Shanghai concessions than those in other cities, examining the nonShanghai concessions enhances our assessment of how different legal system operating within one country shape financial development.

Specifically, we examine 16 Western concessions in three cities-Tianjin, Hankou, and Guangzhou - that operated in China between circa 1860 and 1943 . We choose these three cities because they hosted both concessions with a British common law tradition and 
concessions with civil law legal traditions. ${ }^{14}$ Therefore, we can compare financial development in common law and the civil law jurisdictions within the same city as we did in the context of Shanghai. To conduct these comparisons, we implement two strategies. First, we divide these concessions into two groups: those with a common law legal tradition (Britain and the United States) and those with a civil law tradition (Austro-Hungarian Empire, Belgium, France, German, Italy, Japan, and Russia). ${ }^{15} \mathrm{We}$ then test whether financial development is comparatively stronger in the common law concessions. Second, we focus only on differences between British common law concessions and French civil law concessions in these three cities. This second strategy directly extends our earlier analyses to these three non-Shanghai cities and avoids combining different civil and common law concessions. This second strategy comes at the expense of excluding the other (non-British and non-French) concessions. As we will show, both strategies yield the same conclusions.

Given these data, we estimate the following equation over the period between 1850 (ten years before the establishment of the first concession) and 1936 (the eve of the Second Sino-Japanese War):

$$
Y_{i t}=\beta_{1} \times \text { Common Law } \times \text { Post }+\beta_{2} \times \text { Population density }{ }_{i-1}+\gamma_{i}+\lambda_{t}+\varepsilon i t,
$$

where $Y_{i t}$ denotes the number of banks (per $\mathrm{km}^{2}$ ) in concession $i$, in year $t$. Common Law is a dummy variable that equals one if the concession was granted to a common law country and zero if granted to a civil law country. Post is a dummy variable that equals one after the concession was established and zero otherwise. The estimated coefficient on Common $L a w_{i} \times$ Post provides an estimate of the average annual difference in bank density between common law and civil law concessions. As in the earlier analyses, we control for lagged population density at the concession level (Population density (lag)) and concession and year fixed effect. As noted above, we estimate equation (4) for the full sample of concessions (strategy 1) and for the subsample of concessions that includes only British and French concessions (strategy 2).

\footnotetext{
${ }^{14}$ Ten other cities in China had concessions between circa 1845 and 1945. These other cities, however, had only one concession. For these cities, we cannot compare the common law to civil law within the same city. Therefore, we exclude them from our analysis. Moreover, the Qing dynasty also ceded Kulangsu of Xiamen to ten Western powers (and Japan) as an international settlement. However, there were no clear concession boundaries within Kulangsu, so we exclude Kulangsu.

${ }^{15}$ Supplementary Appendix Table A3 lists each concession, its city, the foreign country (home country) overseeing the concession, and the year the concession was established. Supplementary Appendix B lists data sources.
} 
As reported in Table VII, bank density is materially larger in the common law concessions than in their civil law counterparts. When considering all concessions, we find that, on average, the number of banks per $\mathrm{km}^{2}$ in the common law concessions is 4.4 greater than that in the civil law concessions (column 2). And this gap is mainly driven by differences in the number of Chinese banks, not differences in the number of foreign banks (column 4). While subject to greater data limitations than the analyses focused on the Shanghai concessions, these findings on 16 concessions outside of Shanghai are fully consistent with those comparing the British and French concessions within Shanghai. When considering only British and French concessions in these cities, the results are very similar, as shown in columns (3) and (5). These results provide additional evidence that the common law legal tradition fostered comparatively strong financial development across different concessions within China.

\section{Conclusion}

In this paper, we construct a new database on Western concessions in China from 1845 through 1936 and exploit changes in the degree to which the British common and French civil law traditions held jurisdiction over the respective concessions. We use these data and regime changes to assess the legal origins view of comparative financial development, which stresses that economies with a common law tradition more effectively foster financial development than economies with a civil law tradition. When applied to the Shanghai concessions, the legal origins view predicts that (1) financial development in the British concession should grow comparatively more than that in the French concession after Britain and France establish the Mixed Courts in 1869 and implement British common and French civil law in their respective concessions and (2) financial development in the British concession should shrink comparatively more after the rendition of the Mixed Courts to Chinese rule in 1926.

The evidence is strongly consistent with the legal origins view of comparative financial development. The financial development advantage of the British over the French concession emerges with the application of the British common law and French civil law in the respective concession in 1869. This financial development gap then shrinks after the 1926 rendition of the Mixed Courts that essentially eliminated the application of these Western legal traditions in the concessions. Furthermore, when we extend these analyses across 16 
concessions in three cities outside of Shanghai, we confirm that financial development is materially greater in the common law concessions than in their civil law counterparts. 


\section{References}

Abadie, A., Athey, S., Imbens, G.W. and Wooldridge, J. 2017. When should you adjust standard errors for clustering? NBER Working Paper 24003.

Barth, J. R., Caprio Jr., G., and Levine, R. 2004. Bank regulation and supervision: what works best? Journal of Financial intermediation, 13(2), 205-248.

Beck, T., Demirgüç-Kunt, A. and Levine, R. 2003a. Law, endowments, and finance. Journal of Financial Economics, 70(2), 137-181.

Beck, T., Demirgüç-Kunt, A., and Levine, R. 2003b. Law and finance: why does legal origin matter? Journal of Comparative Economics, 31(4), 653-675.

Beck, T., Levine, R., and Loayza, N. 2000. Finance and the sources of growth. Journal of Financial Economics, 58(1-2), 261-300.

Berkowitz, D. and Clay, K., 2011. The Evolution of a Nation: How Geography and Law Shaped the American States. Princeton University Press, 2011.

Brown, J. R., Cookson, J. A., and Heimer, R. Z. 2017. Law and finance matter: Lessons from externally imposed courts. The Review of Financial Studies, 30(3), 1019-1051.

Brown, J. R., Martinsson, G., and Petersen, B. C. 2013. Law, stock markets, and innovation. The Journal of Finance, 68(4), 1517-1549.

Cai, X. 2013. Wanqing Huayang Shangshi Jiufen Yanjiu (On Sino-foreign Commercial Disputes of the Late Qing Dynasty). Beijing: Zhonghua Shuju.

D’Acunto, F. 2019. From Financial History to History \& Finance. Boston College Working Paper.

D'Acunto, F., Prokopczuk, M., and Weber, M. 2019. Historical Antisemitism, Ethnic Specialization, and Financial Development. Review of Economic Studies 86, 11701206.

Djankov, S., Hart, O., McLiesh, C., and Shleifer, A. 2008. Debt enforcement around the world. Journal of Political Economy, 116(6), 1105-1149.

Djankov, S., La Porta, R., Lopez-de-Silanes, F., and Shleifer, A. 2003. Courts. The Quarterly Journal of Economics, 118(2), 453-517.

Djankov, S., McLiesh, C., and Shleifer, A. 2007. Private credit in 129 countries. Journal of financial Economics, 84(2), 299-329.

Durnev, A., and Kim, E. H. 2005. To steal or not to steal: Firm attributes, legal environment, and valuation. The Journal of Finance, 60(3), 1461-1493. 
Fauvel, A. A. 1899. Histoire de la Concession française de Chang-hai. Paris: E. de Soye et Fils, Imprimeur.

Fisman, R., and Love, I. 2004. Financial development and intersectoral allocation: A new approach. The Journal of Finance, 59(6), 2785-2807.

Glaeser, E. L., and Shleifer, A. 2002. Legal origins. The Quarterly Journal of Economics, 117(4), 1193-1229.

Guiso, L., Sapienza, P., and Zingales, L. 2004. The role of social capital in financial development. American Economic Review, 94(3), 526-556.

Henriot, C., Lu, S., and Aubrun, C. 2018. The Population of Shanghai (1865-1953): A Sourcebook. Leiden; Boston: Brill.

Hou, Q. 2017. Wanqing zhongwai huishen zhidu zhong huayang faguan de falv suyang yu shenpan fengge: Yi Shanghai fazujie huishen gongxie weili (Chinese and foreign judges' trial style and legal literacy in the joint-trial system of late Qing: Evidence from the Mixed-Court of the French concession in Shanghai). Xueshu Yuekan, 49(1), $165-176$

Hudson, M. O. 1927. The rendition of the International Mixed Court at Shanghai. The American Journal of International Law, 21(3), 451-471.

Jappelli, T., Pagano, M., and Bianco, M. 2005. Courts and banks: Effects of judicial Enforcement on Credit Markets. Journal of Money, Credit and Banking, 37(2), 223244.

Jernigan, T. R. 1905. China in law and commerce. New York, NY: Macmillan.

La Porta, R., Lopez-de-Silanes, F., and Shleifer, A. 2006. What works in securities laws? The Journal of Finance, 61(1), 1-32.

La Porta, R., Lopez-de-Silanes, F., and Shleifer, A. 2008. The economic consequences of legal origins. Journal of Economic Literature, 46(2), 285-332.

La Porta, R., Lopez-de-Silanes, F., Shleifer, A., and Vishny, R. W. 1997. Legal determinants of external finance. The Journal of Finance, 52(3), 1131-1150.

La Porta, R., Lopez-de-Silanes, F., Shleifer, A., and Vishny, R. W. 1998. Law and finance. Journal of Political Economy, 106(6), 1113-1155.

La Porta, R., Lopez-de-Silanes, F., Shleifer, A., and Vishny, R. W. 2002. Investor protection and corporate valuation. The Journal of Finance, 57(3), 1147-1170.

Levine, R. 2005. Law, endowments, and property rights. Journal of Economic Perspectives, $19(3), 61-88$. 
Levine, R., Loayza, N., and Beck, T. 2000. Financial intermediation and growth: Causality and causes. Journal of Monetary Economics, 46(1), 31-77.

Licht, A.N., Goldschmidt, C. and Schwartz, S.H., 2005. Culture, law, and corporate governance. International review of law and economics, 25(2), pp.229-255.

Liu, Z. 2004. Jindai Shanghai Huashang Zhengquan Shichang Yanjiu (Studies on Chinese Securities Market in Modern Shanghai). Shanghai: Xuelin Chubanshe.

Maddison, A., 2010. Statistics on world population, GDP, and per capital GDP, 1-2008 AD (Horizontal file), Maddison Historical Statistics. Groningen, the Netherlands: Groningen Growth and Development Centre, University of Groningen.

Montalto de Jesus, C. A. 1919. Historic Shanghai. Shanghai: Shanghai Mercury.

Morck, R., Wolfenzon, D., and Yeung, B. 2005. Corporate governance, economic entrenchment and growth, Journal of Economic Literature 43, 655-720.

Musacchio, A., and Turner, J. D. 2013. Does the law and finance hypothesis pass the test of history? Business History, 55(4), 524-542.

Pagano, M., and Volpin, P. F. 2005. The political economy of corporate governance. American Economic Review, 95(4), 1005-1030.

Perotti, E. C., and Von Thadden, E. L. 2006. The political economy of corporate control and labor rents. Journal of Political Economy, 114(1), 145-175.

Pistor, K. 2009. Rethinking the "law and finance" paradigm. BYU Law Review, 2009(6), $1647-1670$

Rajan, R. G., and Zingales, L. 2003. The great reversals: the politics of financial development in the twentieth century. Journal of Financial Economics, 69(1), 5-50.

Roe, M. J. 2006. Legal origins, politics, and modern stock markets. Harvard Law Reiew, 120, $460-527$.

Safavian, M., and Sharma, S. 2007. When do creditor rights work. Journal of Comparative Economics, 35(3), 484-508.

Shanghai Shehui Kexueyuan (Shanghai Academy of Social Sciences). 1981. Xinghai Geming Zai Shanghai Shiliao Xuanji (Selected Works on the History of Xinhai Revolution in Shanghai). Shanghai: Renmin Chubanshe.

Stulz, R. M., and Williamson, R. 2003. Culture, openness, and finance. Journal of Financial Economics, 70(3), 313-349.

U.S. State Department. 1880. Papers Relating to the Foreign Relations of the United States, Transmitted to Congress, With the Annual Message of the President, December 6, 
1880. US Government Printing Office, 1880. Available at https://history.state.gov/historicaldocuments/frus1880/d133

Wang, L. 1998. Shanghai Fazhishi (Legal History of Shanghai). Shanghai: Renmin Chubanshe

Zou, Y. 1980. Jiu Shanghai Renkou Bianqian de Yanjiu (Studies on the Population Change of Old Shanghai). Shanghai: Renmin Chubanshe. 


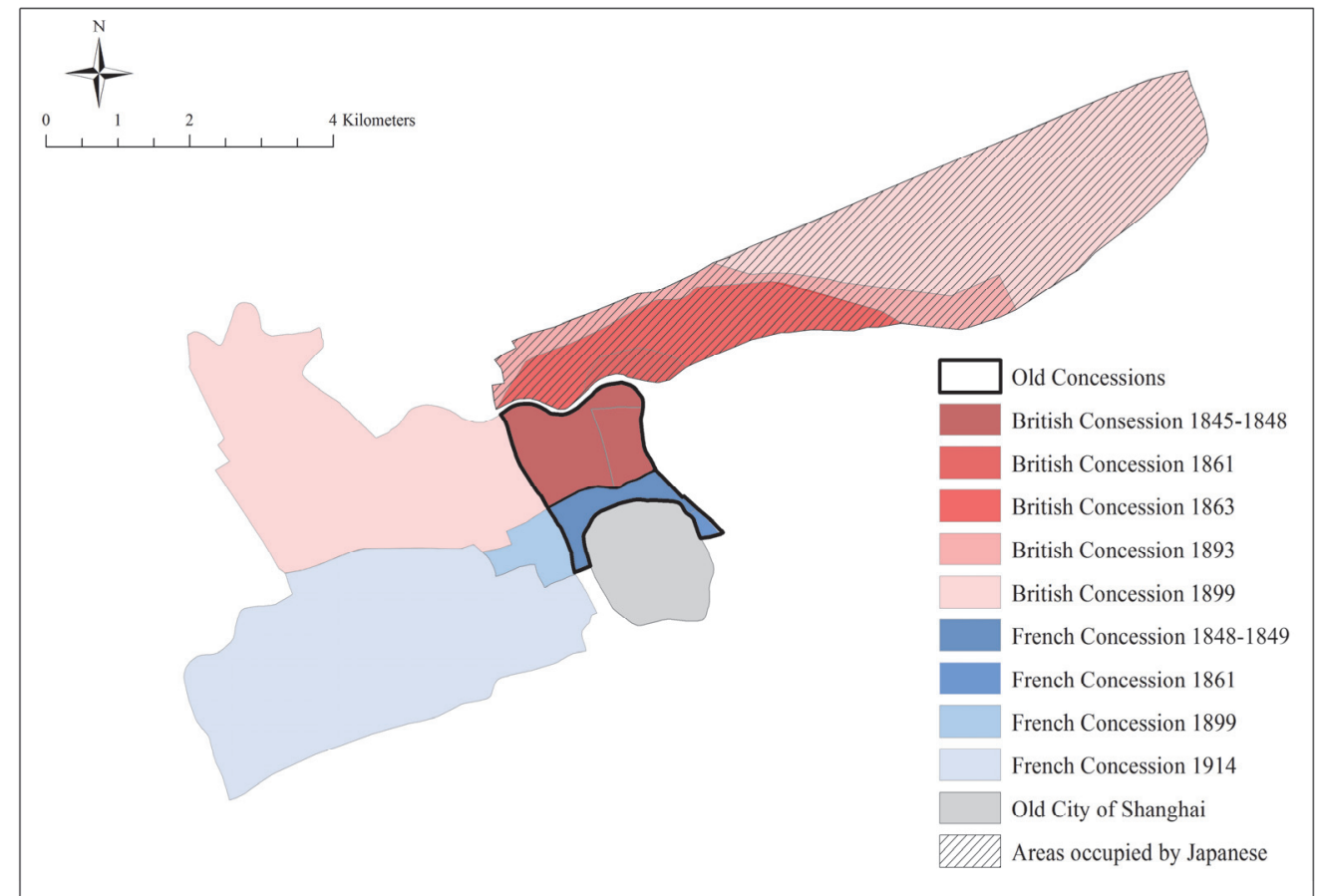

Figure I

Evolution of the Shanghai Concessions

Notes: The figure shows the expansion of the British and French Concessions between 1845 and 1914. The areas in different shades of red depict the British concession at different dates, and those areas highlighted in shades of blue are the French concession. The grey area denotes the Old City of Shanghai County under Chinese administration. The two areas with boundaries outlined with bold, black perimeters, i.e., the dark red and dark blue locations, denote the concessions in 1860, which we call the "old concessions." The old British concession covers 512 acres $\left(2.07 \mathrm{~km}^{2}\right)$, and the old French concession covers 180 acres $\left(0.73 \mathrm{~km}^{2}\right)$. 


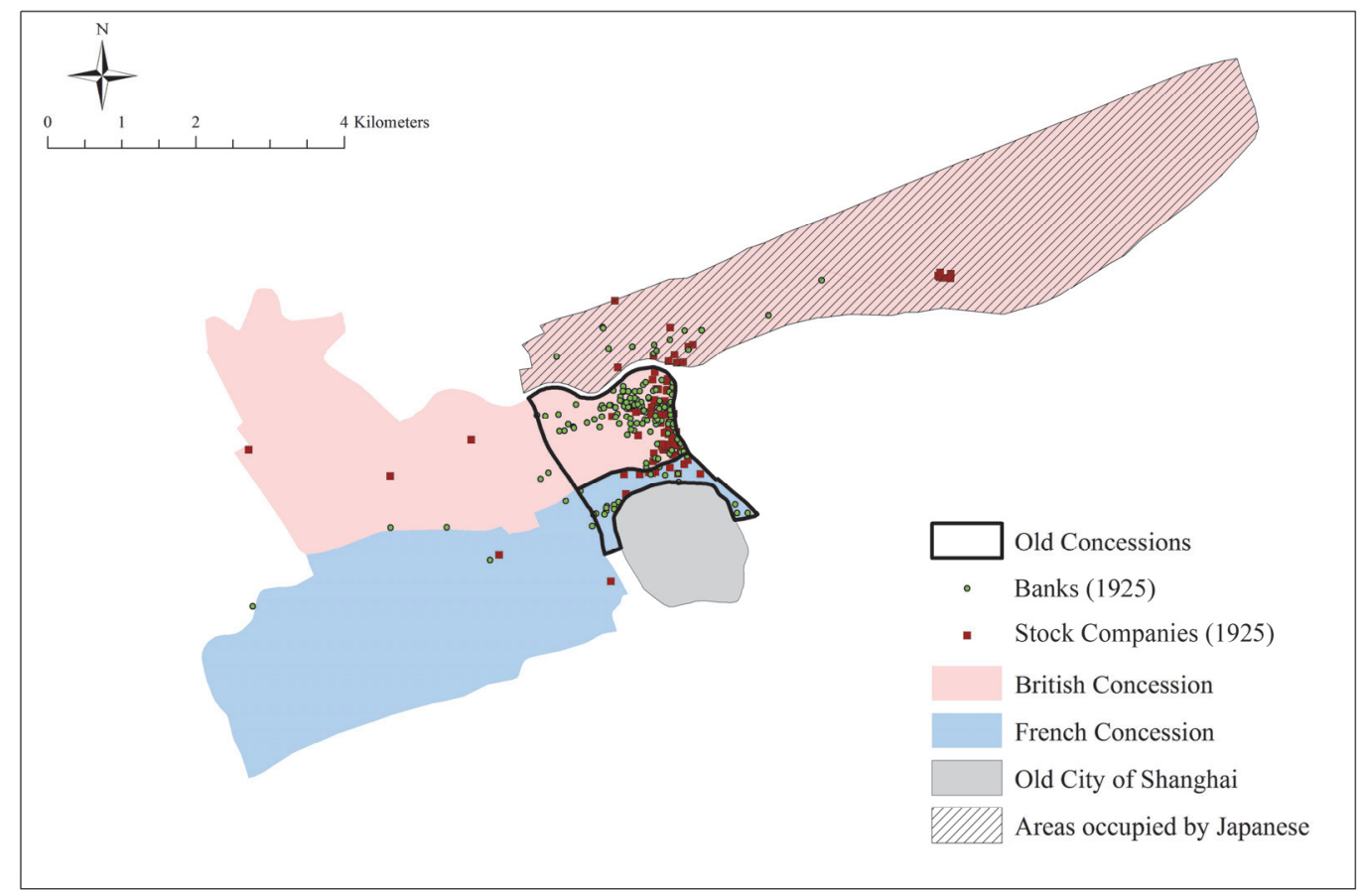

Figure II

Distribution of Banks and Stock Companies in 1925

Notes: The figure shows the distribution of banks and stock companies in the British and French Concessions in Shanghai in 1925. The two areas with boundaries outlined with bold, black perimeters represent our main sample. These are the areas of the concessions in 1860, which we call the "old concessions." 

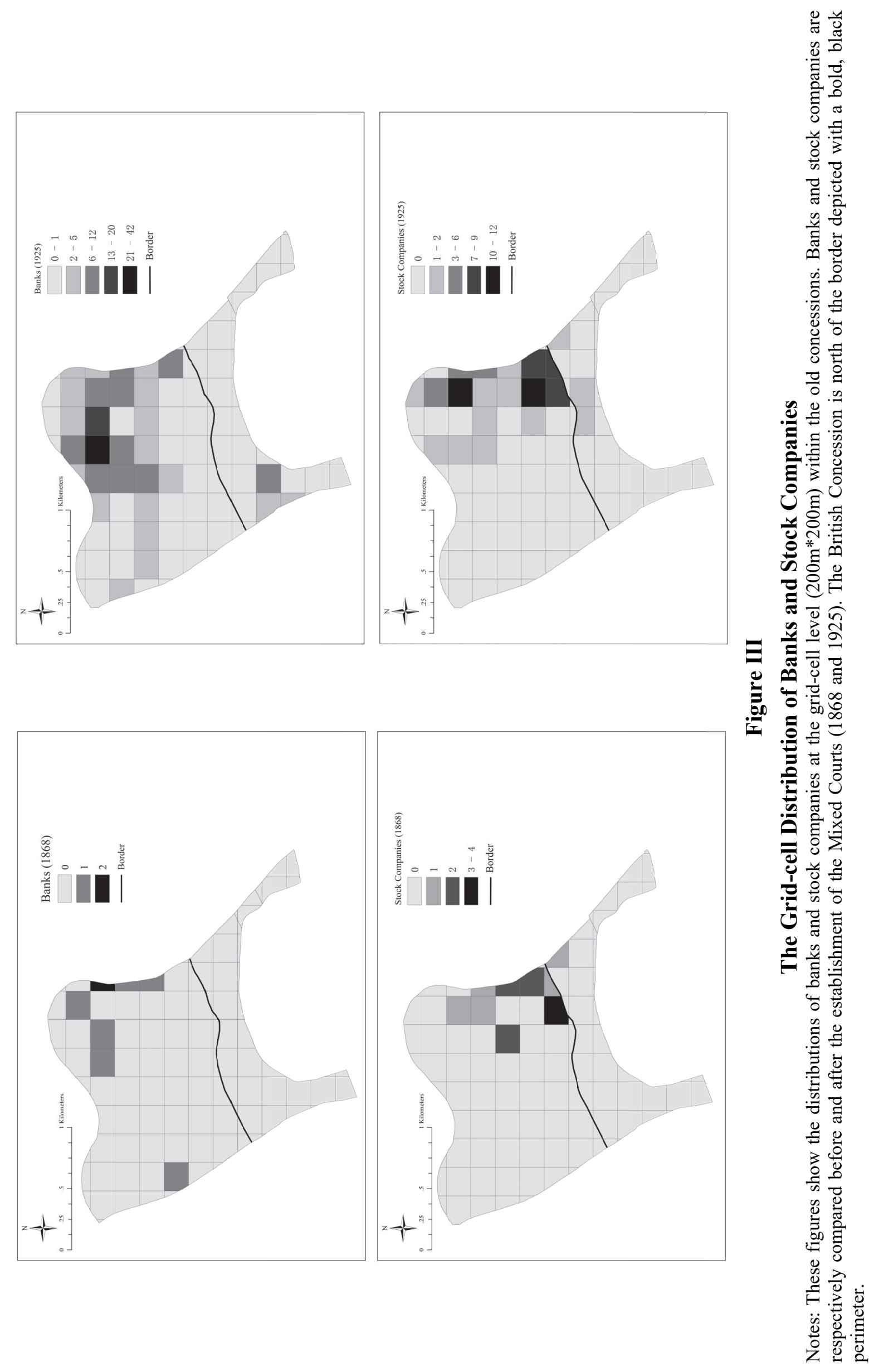


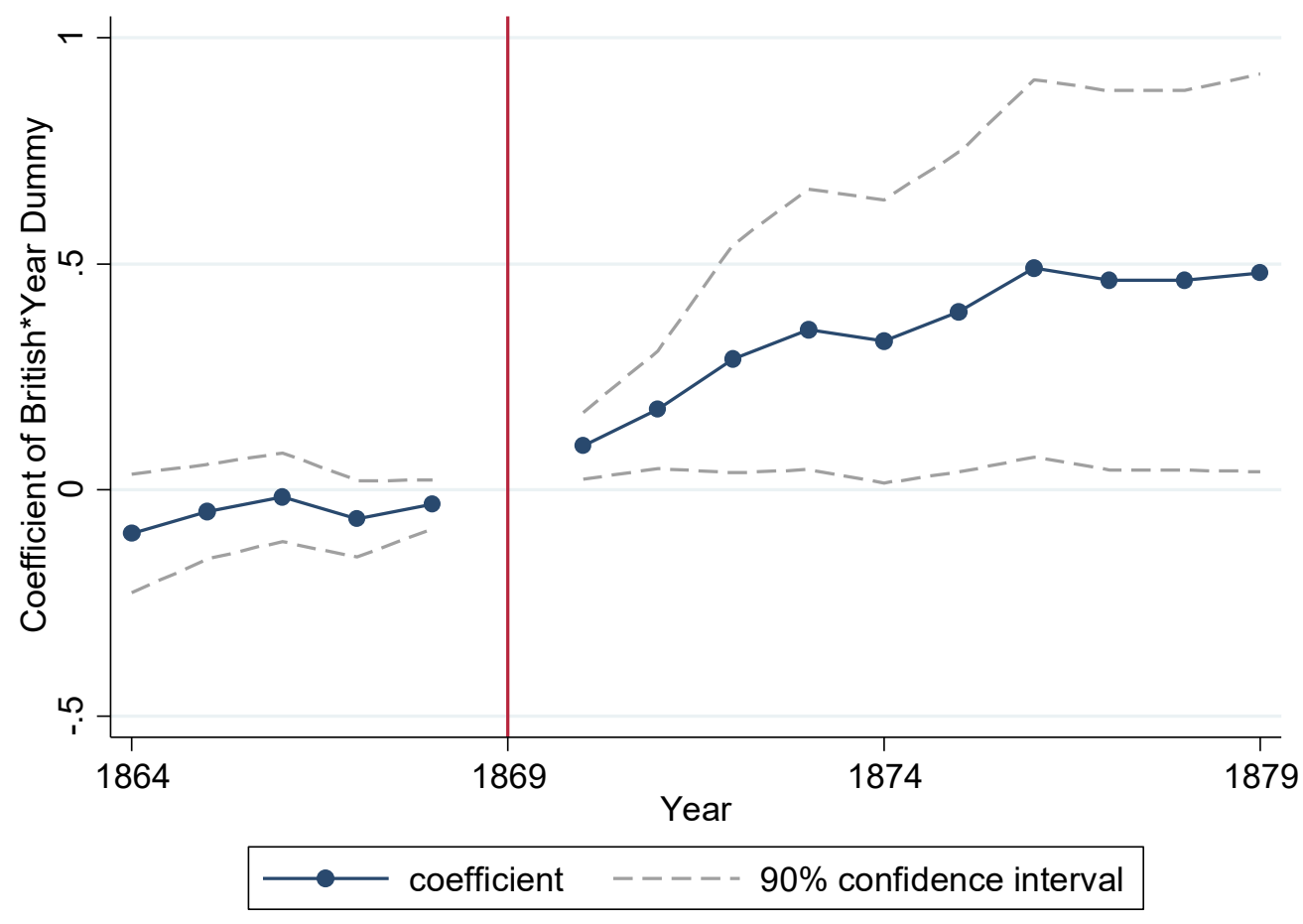

Figure IV

Bank Development and the Creation of the Mixed Courts in 1869

Notes: This figure depicts the estimated annual gap in bank density between the British and French concessions before and after the establishment of the Mixed Courts in 1869. Specifically, we estimate the following regression at the grid-cell level with 1869 as the reference point:

$Y_{i t}=\sum_{t=1864}^{1879} \beta_{t} \times$ British $_{i} \times \theta_{t}+\gamma_{i}+\lambda_{t}+\varepsilon_{i t}$,

where $Y_{i t}$ is the number of banks within gird-cell $i$, in year $t$, and $\theta_{t}$ equals one in year $t$ and zero otherwise, British is dummy variable that equals one for grid cells in the British concession and zero otherwise, $\gamma_{i}$ and $\lambda_{t}$ are grid-cell and year fixed effects respectively. The figure plots the estimated values of and confidence intervals around $\beta_{t}$. 


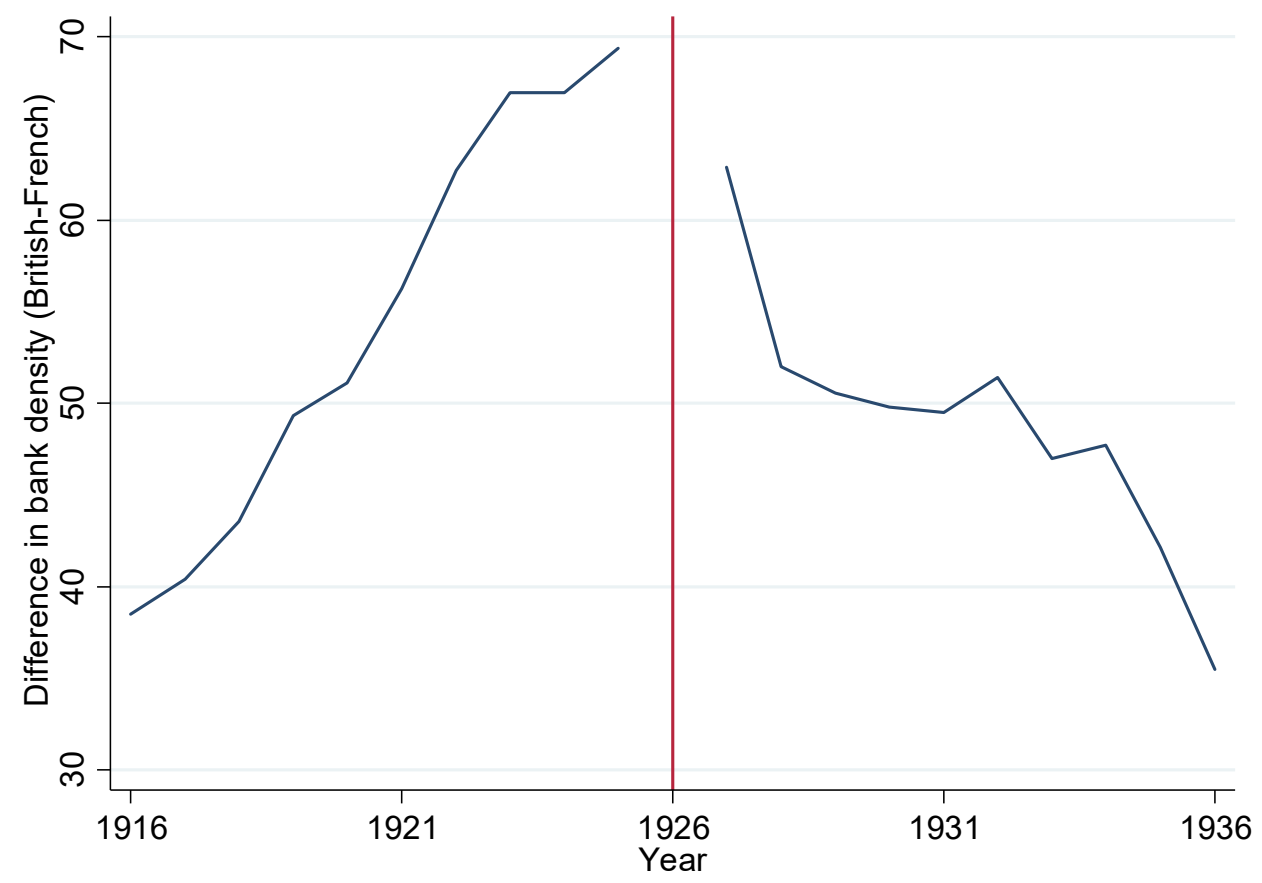

Figure V

The Impact of the Court Rendition on Banking Development

Notes: This figure shows the evolving gap in bank density between the British and the French concessions from ten years before until ten years after the 1926 rendition of the Mixed Courts. 


\section{Table I \\ Bank Density and the Formation of British and French Concessions, 1840-1925}

This table presents regression results relating bank density to the formation of the Shanghai Concessions. In column 1, the dependent variable is the total number of banks per square kilometer in the respective concession in a year. In column 2, the dependent variable is the total number of Chinese-owned banks per square kilometer in the respective concession in a year. In column 3, the dependent variable is the total number of banks per grid cell in a year. In column 4, the dependent variable is the total number of Chinese-owned banks per grid cell in a year. British is a dummy variable that equals one for the British Concession and zero for the French Concession. Post1845 is a dummy variable that equals one after 1845 and equals zero for the years from 1840 through 1845. For the grid-cell analyses, we divide the concessions into $100200 \mathrm{~m}$ by $200 \mathrm{~m}$ grid cells. The regressions control year fixed effects (Year FE) and either Concession fixed effects (Concession FE) or Grid-cell fixed effects (Grid-cell FE) as indicated. Standard errors are reported in parentheses and are clustered at the grid-cell level in columns 3 and $4 . * * *$, and $* * *$ indicate significance at the $10 \%, 5 \%$ and $1 \%$ levels, respectively.

\begin{tabular}{|c|c|c|c|c|}
\hline & \multicolumn{2}{|c|}{ Bank density at the concession level } & \multicolumn{2}{|c|}{ Number of banks at the grid-cell level } \\
\hline & All banks & Chinese banks & All banks & Chinese banks \\
\hline & 1 & 2 & 3 & 4 \\
\hline British * Post1845 & $18.090 * *$ & $14.289 * *$ & $0.669 * * *$ & $0.533 * *$ \\
\hline & $(6.927)$ & $(5.931)$ & $(0.216)$ & $(0.208)$ \\
\hline Year FE & Yes & Yes & Yes & Yes \\
\hline Concession FE & Yes & Yes & & \\
\hline Grid-cell FE & & & Yes & Yes \\
\hline R-Squared & 0.799 & 0.793 & 0.482 & 0.473 \\
\hline Observations & 172 & 172 & 8,600 & 8,600 \\
\hline
\end{tabular}




\section{Table II}

\section{Bank Density and the Formation of the Mixed Courts in the Concessions, 1840-1925}

This table presents regression results relating bank density to the formation of the Shanghai Concessions and the formation of the Mixed Courts in the British and French Concessions. Post1845 indicates the formation of the concessions, so it equals one after 1845 and equals zero for the years from 1840 through 1845. Post1869 indicates the formation of the Mixed Courts, so it equals one after 1869 and equals zero for the years from 1840 through 1869. The note to Table I provides the definition of Chinese banks and grid cells. Standard errors are reported in parentheses and are clustered at the grid-cell level in columns 3 and 4.*,**, and *** indicate significance at the $10 \%, 5 \%$ and $1 \%$ levels, respectively.

\begin{tabular}{|c|c|c|c|c|}
\hline & \multicolumn{2}{|c|}{ Bank density at the concession level } & \multicolumn{2}{|c|}{ Number of banks at the grid-cell level } \\
\hline & All banks & Chinese banks & All banks & Chinese banks \\
\hline & 1 & 2 & 3 & 4 \\
\hline \multirow[t]{2}{*}{ British * Post1845 } & 2.456 & 0.584 & $0.082 * * *$ & $0.019 * *$ \\
\hline & $(5.953)$ & $(5.023)$ & $(0.030)$ & $(0.009)$ \\
\hline \multirow[t]{2}{*}{ British * Post 1869} & $22.334 * * *$ & $19.579 * * *$ & $0.839 * * *$ & $0.733 * *$ \\
\hline & $(3.182)$ & $(2.685)$ & $(0.297)$ & $(0.289)$ \\
\hline Year FE & Yes & Yes & Yes & Yes \\
\hline Concession FE & Yes & Yes & & \\
\hline Grid-cell FE & & & Yes & Yes \\
\hline R-Squared & 0.874 & 0.874 & 0.490 & 0.480 \\
\hline Observations & 172 & 172 & 8,600 & 8,600 \\
\hline
\end{tabular}




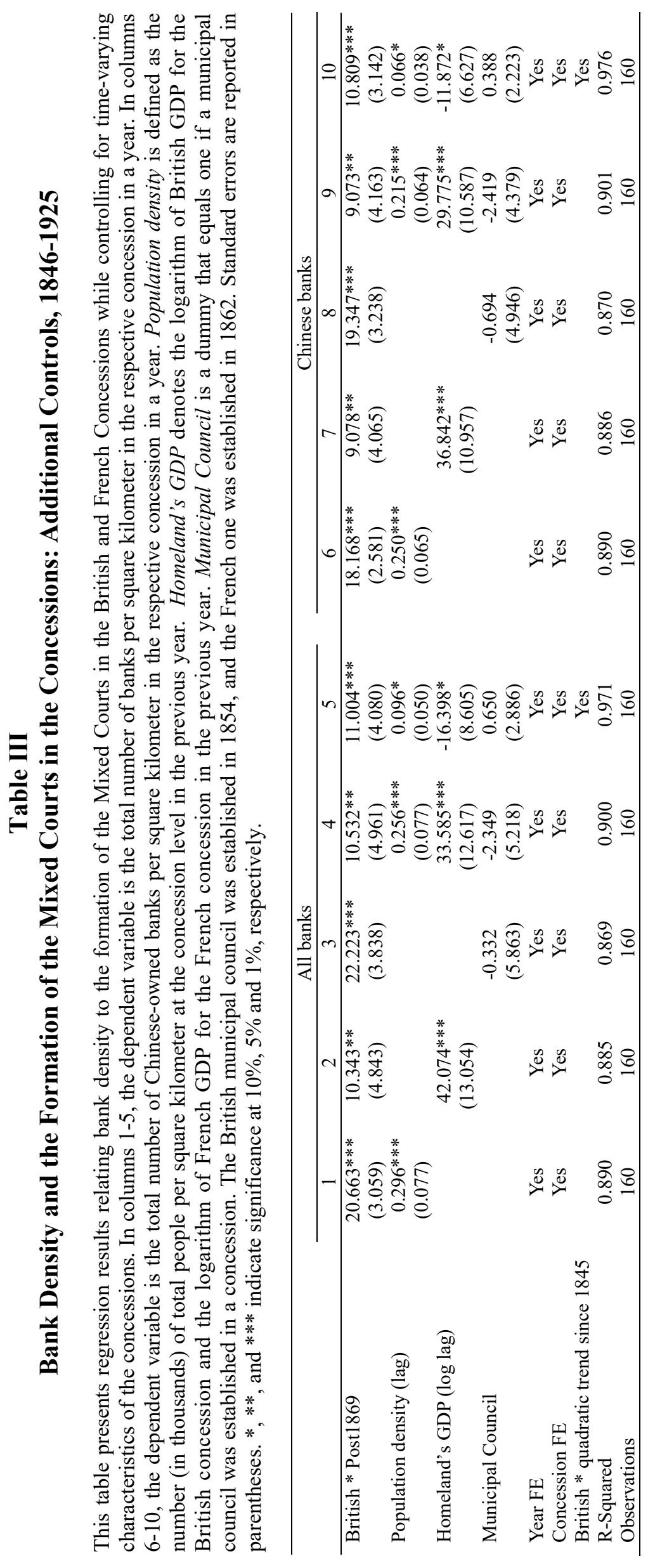




\section{Table IV}

Stock Companies and the Formation of the Mixed Courts in the Concessions, 1866-1925

This table presents regression results relating stock company density to the formation of the Mixed Courts in 1869. In column 1, the dependent variable is the number of stock companies per square kilometer in the respective concession in a year. In column 2, the dependent variable is the number of stock companies per grid cell in a year. British is a dummy variable that equals one for the British Concession and zero for the French Concession. Post1869 equals one after the formation of the Mixed Courts, so it equals one after 1869 and equals zero for the years from 1866 through 1869. The regressions control year fixed effects (Year FE) and either Concession fixed effects (Concession FE) or Grid-cell fixed effects (Grid-cell FE) as indicated. Standard errors are reported in parentheses and are clustered at the grid-cell level in column 2. *,**, and *** indicate significance at the $10 \%, 5 \%$ and $1 \%$ levels, respectively.

\begin{tabular}{lcc}
\hline & $\begin{array}{c}\text { Stock company density at the } \\
\text { concession level }\end{array}$ & $\begin{array}{c}\text { Number of stock companies at the } \\
\text { grid-cell level }\end{array}$ \\
\cline { 2 - 3 } & 1 & 2 \\
\hline British * Post1869 & $10.085^{* *}$ & $0.362^{* *}$ \\
& $(4.904)$ & $(0.157)$ \\
Year FE & Yes & Yes \\
Concession FE & Yes & Yes \\
Grid-cell FE & & 0.554 \\
R-Squared & 0.801 & 6,000 \\
Observations & 120 & \\
\hline
\end{tabular}




\section{Table V \\ Rendition of the Mixed Courts in 1926}

This table examines the comparative changes in bank density, stock company density, and market capitalization between the British and French Concessions after the agreement regarding the rendition of the Mixed Courts in 1926. Bank density and stock company density equal, respectively, the annual number of banks and stock companies per square kilometer in the respective concession. Market capitalization equals the annual total market capitalization of stock companies in a concession per square kilometer. In columns 1-3, the sample period is from 1917 to 1936, i.e., the 10-year window around the court rendition. In columns 4-6, the sample period is from 1922 to 1931, i.e., the 5-year window around the rendition. The regressions control year fixed effects (Year FE) and Concession fixed effects (Concession FE). Standard errors are reported in parentheses. *, $* *$, and $* * *$ indicate significance at $10 \%, 5 \%$ and $1 \%$, respectively.

\begin{tabular}{|c|c|c|c|c|c|c|}
\hline & \multicolumn{3}{|c|}{ Period of analysis is $1917-1936$} & \multicolumn{3}{|c|}{ Period of analysis is $1922-1931$} \\
\hline & $\begin{array}{l}\text { Bank } \\
\text { density }\end{array}$ & $\begin{array}{c}\text { Stock } \\
\text { company } \\
\text { density }\end{array}$ & $\begin{array}{c}\text { Market- } \\
\text { capitalization }\end{array}$ & $\begin{array}{c}\text { Bank } \\
\text { density }\end{array}$ & $\begin{array}{c}\text { Stock } \\
\text { company } \\
\text { density }\end{array}$ & $\begin{array}{c}\text { Market- } \\
\text { capitalization }\end{array}$ \\
\hline & 1 & 2 & 3 & 4 & 5 & 6 \\
\hline British * Post 1926 & $\begin{array}{l}-8.246^{*} \\
(3.988)\end{array}$ & $\begin{array}{c}-11.594 * * * \\
(1.967)\end{array}$ & $\begin{array}{l}-1.272 * * * \\
(0.205)\end{array}$ & $\begin{array}{c}-13.099 * * * \\
(2.779)\end{array}$ & $\begin{array}{l}-6.010 * * * \\
(1.702)\end{array}$ & $\begin{array}{l}-0.713 * * \\
(0.251)\end{array}$ \\
\hline Year FE & Yes & Yes & Yes & Yes & Yes & Yes \\
\hline Concession FE & Yes & Yes & Yes & Yes & Yes & Yes \\
\hline R-Square & 0.980 & 0.973 & 0.986 & 0.996 & 0.992 & 0.990 \\
\hline Observations & 40 & 40 & 40 & 20 & 20 & 20 \\
\hline
\end{tabular}




\section{Table VI}

\section{Stock Returns and the Rendition of the Mixed Courts}

This table provides regression results relating stock returns to the rendition of the Mixed Courts to Chinese jurisdiction. The dependent variable is a firm's monthly stock return, defined as the log difference of month-end prices, i.e., $\log \left(\right.$ price $\left._{t}\right)-\log \left(\right.$ price $\left._{t-1}\right)$. The sample period is from September 1925 through August of 1927, i.e., a 24-month window around the month of the court rendition announcement. Post-Rendition is a dummy that equals one for the months after the August 1926 rendition announcement. Firm controls include the log duration (of months) since the firm went public (listed) and the log market capitalization. Firm FE refers to the firm fixed effects that absorb all time-invariant firm characteristics. Standard errors are clustered at the firm level and reported in parentheses. $* * *$, and $* * *$ indicate significance at $10 \%, 5 \%$ and $1 \%$, respectively.

\begin{tabular}{lcccc}
\hline & \multicolumn{4}{c}{ Stock return } \\
\cline { 2 - 4 } & 1 & 2 & 3 & 4 \\
\hline Post-Rendition & $-0.049^{* * *}$ & $-0.055^{* * *}$ & -0.001 & 0.003 \\
British * Post-Rendition & $(0.007)$ & $(0.009)$ & $(0.006)$ & $(0.007)$ \\
& & & $-0.051^{* * *}$ & $-0.060^{* * *}$ \\
British & & & $(0.010)$ & $(0.010)$ \\
& & & $0.038^{* * *}$ & \\
Firm controls & & & $(0.008)$ & Yes \\
Firm FE & Yes & Yes & Yes & Yes \\
R-squared & No & Yes & 0.017 & 0.063 \\
Observations & 0.017 & 0.062 & 2,909 & 2,909 \\
\hline
\end{tabular}




\section{Table VII \\ Legal Origins and Finance: Concessions in other Chinese Cities, 1850-1936}

This table provides regression results relating bank density to the legal origin of the foreign entity with legal jurisdiction over 16 concessions in three cities (Tianjin, Hankou, and Guangzhou). Appendix Table A4 provides details on the countries and legal traditions with jurisdiction over these concessions. In columns 1-3, the dependent variable is the total number of banks per square kilometer in the respective concession in a year. In columns 4 and 5, the dependent variable is the total number of Chinese-owned banks per square kilometer in the respective concession in a year. Common Law is a dummy variable that equals one for the concessions ruled by common law countries and zero for the concessions ruled by civil law countries. Post is a dummy variable that equals one after the concession was established. Population density is the number (in thousands) of total people per square kilometer at the concession-year level. In columns 3 and 5, we restrict the analysis to only the concessions of Britain and France to compare the British common law to French civil law. The regressions control for year fixed effects (Year FE) and Concession fixed effects (Concession FE) as indicated. Standard errors clustered at the concession and year levels are reported in parentheses. *, **, and *** indicate significance at the $10 \%, 5 \%$ and $1 \%$ levels, respectively.

\begin{tabular}{|c|c|c|c|c|c|}
\hline & \multicolumn{3}{|c|}{ All banks } & \multicolumn{2}{|c|}{ Chinese banks } \\
\hline & $\begin{array}{c}\text { All } \\
\text { concessions }\end{array}$ & $\begin{array}{c}\text { All } \\
\text { concessions }\end{array}$ & $\begin{array}{l}\text { British vs. } \\
\text { French } \\
\text { concessions }\end{array}$ & $\begin{array}{c}\text { All } \\
\text { concessions }\end{array}$ & $\begin{array}{l}\text { British vs. } \\
\text { French } \\
\text { concessions } \\
5\end{array}$ \\
\hline & 1 & 2 & 3 & 4 & 5 \\
\hline Common Law * Post & $\begin{array}{l}5.320 * * * \\
(0.996)\end{array}$ & $\begin{array}{l}4.393 * * * \\
(1.139)\end{array}$ & $\begin{array}{l}3.793 * * \\
(1.764)\end{array}$ & $\begin{array}{l}3.807 * * * \\
(1.053)\end{array}$ & $\begin{array}{l}3.076^{* *} \\
(1.210)\end{array}$ \\
\hline Population density (lag) & & $\begin{array}{l}0.134 * * * \\
(0.028)\end{array}$ & $\begin{array}{l}0.227^{* * *} \\
(0.020)\end{array}$ & $\begin{array}{l}0.133^{* * * *} \\
(0.028)\end{array}$ & $\begin{array}{l}0.229 * * * \\
(0.030)\end{array}$ \\
\hline Year FE & Yes & Yes & Yes & Yes & Yes \\
\hline Concession FE & Yes & Yes & Yes & Yes & Yes \\
\hline R-Squared & 0.347 & 0.435 & 0.629 & 0.429 & 0.622 \\
\hline Observations & 1,392 & 1,392 & 522 & 1,392 & 522 \\
\hline
\end{tabular}




\section{Supplementary Appendix}

\section{A. Figures and Tables}

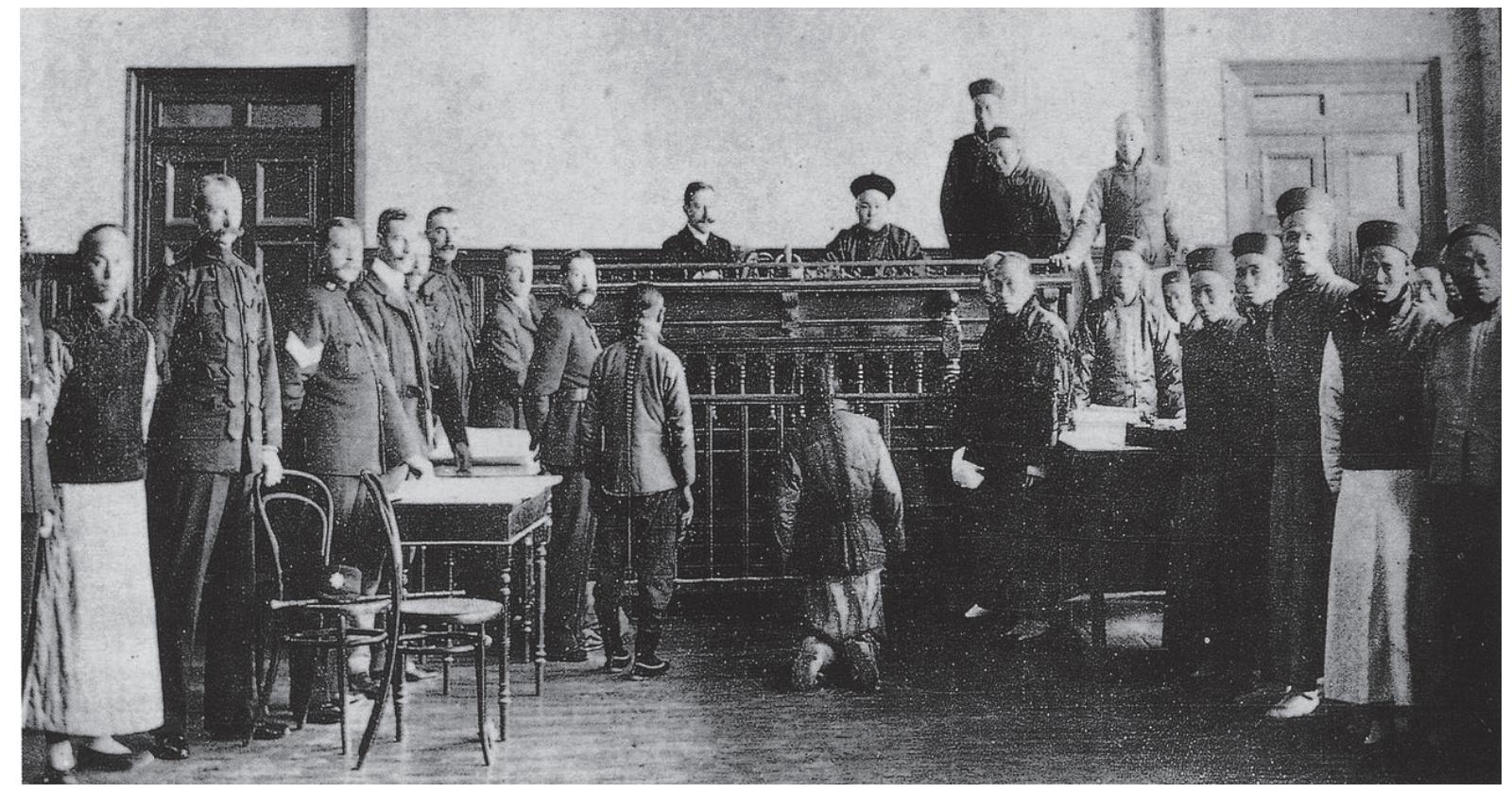

Figure A1. The Mixed Court at the British Concession of Shanghai (1869 to 1927)

Source: Wikipedia,

https://commons.wikimedia.org/wiki/File:International_Mixed_Court_at_Shanghai7.jpg 


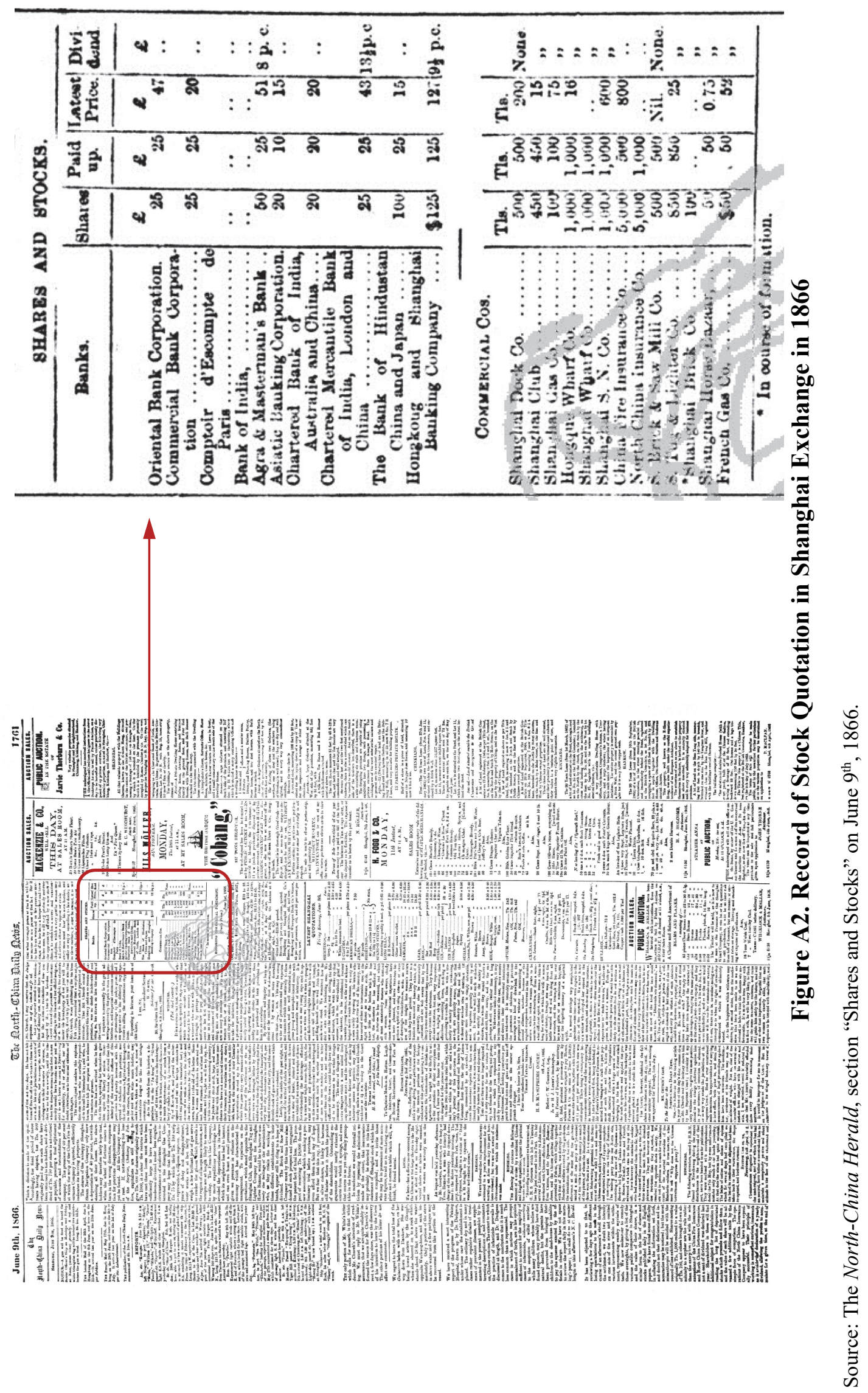




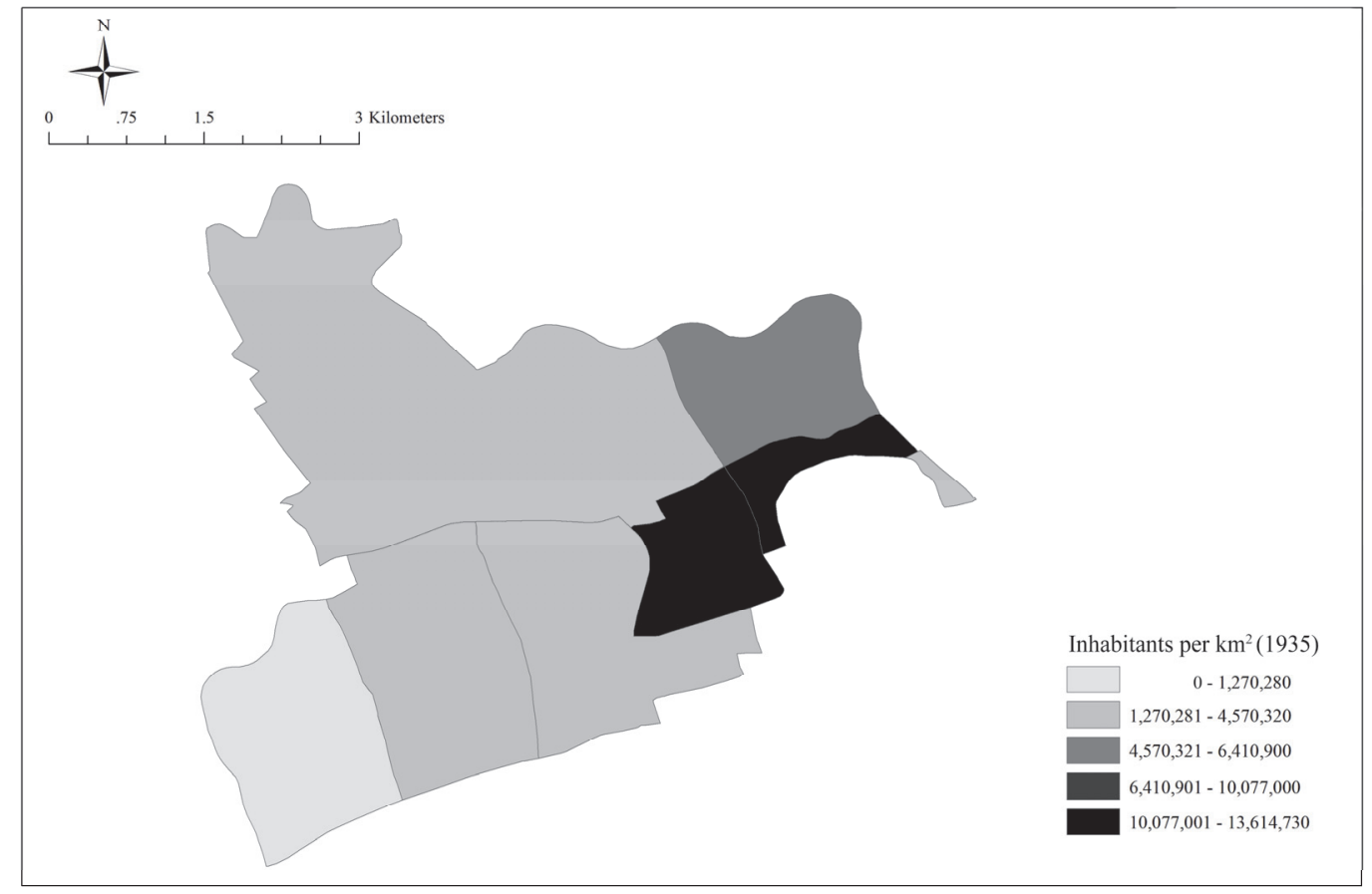

Figure A3. Population Density in 1935

Notes: This figure depicts the population density by census district in Shanghai concessions in 1935, based on Henriot et al. (2018). 
Table A1. Summary Statistics

\begin{tabular}{|c|c|c|c|c|c|}
\hline Variable & Obs. & Mean & S.D. & Min & Max \\
\hline \multicolumn{6}{|l|}{ Concession-year level } \\
\hline Bank density & 194 & 17.821 & 25.074 & 0 & 95.652 \\
\hline Chinese bank density & 194 & 14.788 & 21.517 & 0 & 82.609 \\
\hline Stock company density & 142 & 12.231 & 11.291 & 0 & 36.715 \\
\hline Market capitalization (in 1,000 Taels per $\mathrm{km}^{2}$ ) & 86 & $50,605.35$ & $65,551.21$ & 404.11 & $241,102.3$ \\
\hline Population density $\left(1,000\right.$ habitants per $\left.\mathrm{km}^{2}\right)$ & 194 & 38.156 & 21.503 & 3.248 & 112.779 \\
\hline Homeland's GDP (in Int. GK\$) & 194 & $125,674.9$ & $59,782.19$ & 49,828 & $284,141.8$ \\
\hline \multicolumn{6}{|l|}{ Grid-year level } \\
\hline Number of banks & 9,700 & 0.629 & 2.573 & 0 & 47 \\
\hline Number of Chinese banks & 9,700 & 0.515 & 2.432 & 0 & 47 \\
\hline Number of stock companies & 7,100 & 0.445 & 1.636 & 0 & 21 \\
\hline Market capitalization (in 1,000 Taels) & 6,492 & $1,341.825$ & $10,087.21$ & 0 & $213,904.1$ \\
\hline \multicolumn{6}{|l|}{ Firm-month level } \\
\hline Stock return (September 1925-August 1927) & 3,356 & -0.005 & 0.232 & -4.520 & 3.401 \\
\hline
\end{tabular}


Table A2. Bank Density and the Formation of the Mixed Courts in the Concessions: Alternative Samples

This table replicates Table II except for restricting the period to the Qing dynasty (1840-1910) (Panel A) and using the 5-year data (Panel B). Standard errors are reported in parentheses and are clustered at the grid-cell level in columns 3 and $4 . * * *$, and $* * *$ indicate significance at $10 \%, 5 \%$ and $1 \%$, respectively.

\begin{tabular}{|c|c|c|c|c|}
\hline & \multicolumn{2}{|c|}{ Concession level } & \multicolumn{2}{|c|}{ Grid-cell level } \\
\hline & 1 & 2 & 3 & 4 \\
\hline & \multicolumn{4}{|c|}{ Qing dynasty, 1840-1910 } \\
\hline British * Post1845 & $\begin{array}{l}11.553^{* * *} \\
(3.436)\end{array}$ & $\begin{array}{c}2.456 \\
(2.015)\end{array}$ & $\begin{array}{l}0.414 * * * \\
(0.140)\end{array}$ & $\begin{array}{l}0.082 * * * \\
(0.030)\end{array}$ \\
\hline British * Post1869 & & $\begin{array}{l}14.422 * * * \\
(1.135)\end{array}$ & & $\begin{array}{l}0.526^{* *} \\
(0.206)\end{array}$ \\
\hline Year FE & Yes & Yes & Yes & Yes \\
\hline Concession FE & Yes & Yes & & \\
\hline Grid-cell FE & & & Yes & Yes \\
\hline R-Squared & 0.813 & 0.944 & 0.512 & 0.522 \\
\hline Observations & 142 & 142 & 7,100 & 7,100 \\
\hline Panel B & \multicolumn{4}{|c|}{ Five-year data, 1840-1925 } \\
\hline British * Post1845 & $\begin{array}{c}19.637 \\
(13.654)\end{array}$ & $\begin{array}{c}2.415 \\
(13.640)\end{array}$ & $\begin{array}{l}0.729 * * * \\
(0.232)\end{array}$ & $\begin{array}{l}0.081 * * \\
(0.031)\end{array}$ \\
\hline British * Post1869 & & $\begin{array}{l}22.962^{* *} \\
(9.093)\end{array}$ & & $\begin{array}{l}0.865^{* * *} \\
(0.303)\end{array}$ \\
\hline Year FE & Yes & Yes & Yes & Yes \\
\hline Concession FE & Yes & Yes & & \\
\hline Grid-cell FE & & & Yes & Yes \\
\hline R-Squared & 0.803 & 0.862 & 0.468 & 0.475 \\
\hline Observations & 36 & 36 & 1,800 & 1,800 \\
\hline
\end{tabular}


Table A3. Other Concessions in China between 1860 and 1936

\begin{tabular}{|c|c|c|c|c|}
\hline City & Concession & Home Country & Legal origin & $\begin{array}{c}\text { Year of } \\
\text { establishment }\end{array}$ \\
\hline \multirow[t]{9}{*}{ Tianjin } & British concession in Tientsin & Britain & Common & 1860 \\
\hline & American concession in Tientsin & United States & Common & 1860 \\
\hline & $\begin{array}{l}\text { French concession in Tianjin (Concession } \\
\text { française de Tientsin) }\end{array}$ & France & Civil & 1861 \\
\hline & German concession in Tianjin & Germany & Civil & 1895 \\
\hline & Japanese concession in Tianjin & Japan & Civil & 1898 \\
\hline & Russian concession in Tianjin & Russia & Civil & 1900 \\
\hline & $\begin{array}{l}\text { Italian concession in Tianjin (La Concessione } \\
\text { italiana di Tientsin) }\end{array}$ & Italy & Civil & 1902 \\
\hline & Austro-Hungarian concession in Tianjin & Austro-Hungary & Civil & 1902 \\
\hline & Belgian concession in Tianjin & Belgium & Civil & 1902 \\
\hline \multirow[t]{5}{*}{ Hankou } & British Concession in Hankou & Britain & Common & 1861 \\
\hline & French Concession in Hankou & France & Civil & 1896 \\
\hline & Japanese concession in Hankou & Japan & Civil & 1898 \\
\hline & Russian concession in Hankou & Russia & Civil & 1896 \\
\hline & German concession in Hankou & Germany & Civil & 1895 \\
\hline \multirow[t]{2}{*}{ Guangzhou } & British concession in Shamian Island & Britain & Common & 1861 \\
\hline & French Concession in Shamian Island & France & Civil & 1861 \\
\hline
\end{tabular}




\section{Appendix B. Data Sources}

\section{Data sources for banks}

Bank of Communications. 1995. Zhongguo Jiaotong Yinhang Shiliao, Diyijuan: 1907-1949 (Historical Materials on the Chinese Bank of Communications, Volume One: 19071949). Beijing: Zhongguo Jinrong Chubanshe.

$\mathrm{Bu}$, M. 1995. Zhongguo Yinhang Hangshi, 1912-1949 (The History of the Bank of China, 1912-1949). Beijing: Zhongguo Jinrong Chubanshe.

Chen, X., Gu, T., and Wang, W. 2000. Zhongguo Tongshang Yinhang (The Imperial Bank of China). Shanghai: Shanghai Renmin Chubanshe.

Ge, Y. 2009. Huyou Zaji (Shanghai Travel Miscellanea). Shanghai: Shanghai Shudian Chubanshe.

Jiang, H. 1990. Zhongguo Difang Yinhangshi (A History of Local Banks in China). Changsha: Hunan Chubanshe.

Jiang, J. 2014. Jindai Zhongguo Yinhangye Jigou Renming Dacidian (Dictionary of Modern Chinese Banking Institutions and Personages). Shanghai: Shanghai Guji Chubanshe.

Li, Q., and Zhao, W. 1978. Shanghai Zhi Qianzhuang (The Money Houses in Shanghai). Taipei: Huashi Chubanshe.

Lin, Z. 1928. Shanghai Shangye Minglu (Shanghai Business Directory). Shanghai: The Commercial Press.

North China Daily News. 1872-1941. The North-China Desk Hong List (1872-1941). Shanghai: North China Daily News.

Quanguo Tushuguan Wenxian Suowei Fuzhi Zhongxin. 2010. Minguo Shiqi Shanghai Shiliao Wenxian Congbian, Diyice (Historical Materials of Shanghai in the Republican Period, First Volume). Beijing: Quanguo Tushuguan Wenxian Suowei Fuzhi Zhongxin.

Shanghai Tongshe. 1984. Shanghai Yanjiu Ziliao Xubian (Continuation of Shanghai Study Materials). Shanghai: Shanghai Shudian Chubanshe.

Shangwu Yinshuguan Bianyisuo. 1922, 1925, 1930, and 1936. Shanghai Zhinan (Shanghai Directory). Shanghai: The Commercial Press.

The People's Bank of China Shanghai Branch. 1960. Shanghai Qianzhuang Shiliao (Historical Materials on Money Houses in Shanghai). Shanghai: Shanghai Renmin Chubanshe.

Wang, Z. 1934. Zhongguo zhi Chuxu Yinhang Shi (A History of Savings Banks in China). Beijing: Zhishi Chanquan Chubanshe.

Xu, K. 1920. Shanghai Shangye Minglu (Shanghai Business Directory). Shanghai: The Commercial Press.

Zhongguo Yinhang Jingji Yanjiushi. 1934-1937. Quanguo Yinhang Nianjian (National Banking Yearbook). Beijing: Zhongguo Yinhang Jingji Yanjiushi.

\section{Data source for population in other concessions of China}

Chen, W., and Lai, X. 2004. Tianjin de Renkou Bianqian (Population Change in Tianjin). Tianjin: Tianjin Guji Chubanshe.

Fei, C. 1991. Zhongguo Zujie Shi (Concessions in Historical China). Shanghai: Shanghai Shehui Kexueyuan Chubanshe.

Guangzhou Difangzhi Bianzuan Weiyuanhui Bangongshi. 1995. Jindai Guangzhou Kou-an Jingji Shehui Gaikuang (Social-Economic Overview of Modern Guangzhou Port). Jinan: Jinan Daxye Chubanshe. 
Huang, X. 1990. Zhenjiang Wenshi Ziliao (Literature and History Materials of Zhenjiang). Beijing: Zhongguo Wenshi Chubanshe.

Jin, P., and He, Y. 1989. Hangzhou Gongchenqiao Rizujie de Jige Wenti (Issues on the Japanese Concession in Hangzhou Gongchenqiao), Hangzhou Daxue Xuebao, Zhexue Shehui Kexue Ban, 4, 144-153.

Jin, P., and He, Y. 1992. Hangzhou Gongchenqiao Rizujie dui Hangzhou de Yingxiang (The Impact of Gongchenqiao Japanese Concession on Hangzhou). Hangzhou Daxue Xuebao, Zhexue Shehui Kexue Ban, 1, 110-117.

Li, G., and Lin, W. 2006. Qingdai Guangzhou Shisanhang Jilue (A Brief Account of the Thirteen Hongs of Guangzhou in the Qing Dynasty). Guangzhou: Guangdong Renmin Chubanshe.

Li, J. 1990. Tianjin Renkou Shi (Population History of Tianjin). Tianjin: Nankai Daxue Chubanshe.

Osato, H., and Son, A. 2011. Zujie Yanjiu Xin Dongtai (Perspective of the Concession Studies). Shanghai: Shanghai Renmin Chubanshe.

Tianjin Dang-an Guan. 1992. Tianjin Zujie Dang-an Xuanbian (Selected Archives of Tianjin Concession). Tianjin: Tianjin Renmin Chubanshe.

Tianjinshi Difangzhi Bianxiu Weiyuanhui. 2001. Tianjin Tongzhi (Gazetteer of Tianjin). Tianjin: Tianjin Renmin Chubanshe.

Yuan, J. 2003. Hankou Zujie Zhi (History of Hankou Concession). Wuhan: Wuhan Chubanshe.

Zhang, H. 1993. Tianjin de Renkou Bianqian (Population Changes in Tianjin). Tianjin: Tianjin Renmin Chubanshe.

Zhengxie Wuhu Xian Wenshi Weiyuanhui. 1994. Wuhu Xian Wenshi Ziliao, Di Si Ji (Literature and History Materials of Wuhu Xian, Volume 4). Beijing: Zhongguo Wenshi Chubanshe.

Zhongguo Renmin Zhengzhi Xieshang Huiyi Guangzhoushi Weiyuanhui Wenshi Ziliao Yanjiu Weiyuanhui. 1991. Guangzhou Wenshi Ziliao (Literature and History Materials of Guangzhou). Guangzhou: Guangdong Renmin Chubanshe.

Zhou, D. 2009. Hankou de Zujie: Yixiang Lishi Shehuixue de Kaocha (The Concession of Hankou: A Survey Based on Historical Sociology). Tianjin: Tianjin Jiaoyu Chubanshe. 